\title{
Morphologic and hydrodynamic controls on the occurrence of tidal bundles in an open-coast macrotidal environment, northern Gyeonggi Bay, west coast of Korea
}

\author{
Kyungsik Choi * , Do Hyeong Kim \\ School of Earth and Environmental Sciences \& Research Institute of Oceanography, Seoul National University, Republic of Korea
}

\section{A R T I C L E I N F O}

\section{Article history:}

Received 11 February 2016

Received in revised form 12 April 2016

Accepted 13 April 2016

Available online 22 April 2016

Editor: Dr. J. Knight

\section{Keywords:}

Dune

Tidal bundle

Time-velocity asymmetry

Tidal channel

Open-coast tidal flat

Velocity peak asymmetry

\begin{abstract}
A B S T R A C T
Tidal dunes with well-defined rhythmic tidal bundles are documented from the lower intertidal zone of an open-coast macrotidal environment in Gyeonggi Bay, Korea. Based on combined morphologic, sedimentologic and hydrodynamic datasets, this study aims to characterize the factors that govern the temporal and spatial variability of tidal bundles in a non-barred, unconfined macrotidal environment. The tidal dunes are floodasymmetric and of longer wavelength $(10-20 \mathrm{~m})$ with small ebb caps on the upper bank, and symmetric to slightly ebb-asymmetric and of shorter wavelength (5-10 m) with larger ebb caps on the lower bank. The upper-bank dunes are characterized by more steeply dipping flood-directed planar cross-beds and thinner mud drapes than the lower-bank dunes. Each tidal bundle consists of a single mud drape that is stratified to cross-stratified, rich in silt and very fine sand. It overlies ebb-directed ripples and represents dynamic mud deposition during the ebb tidal phase. The presence of strong rotary currents (up to $0.25 \mathrm{~m} / \mathrm{s}$ ) and low suspended-sediment concentration of flood currents prevent deposition of mud drapes during the high-tide slack-water period. The distinct asymmetry in the water elevation at which the velocity peaks during the ebb and flood phases results in the preferential preservation of flood-directed cross-beds in the lower intertidal zone, where the ebb current - although stronger than the flood currents - is of shorter duration and hence unable to reverse the dune profile. The pronounced time-velocity asymmetry at the higher elevation combined with the distinct velocity peak asymmetry leads to a better preservation of hierarchical tidal cycles in the upper-bank dunes. The present study suggests that the persistent occurrence of single, stratified to cross-stratified mud drapes, which reflect dynamic mud deposition during the ebb phase, and the dominance of flood-directed cross-beds are diagnostic features of tidal bundles in the intertidal zone of unbarred, open-coast macrotidal environments. A proposed model for mud drape deposition provides a new perspective on the origin of tidal bundles together with useful criteria for reconstructing the paleo-depositional setting.
\end{abstract}

다 2016 Elsevier B.V. All rights reserved.

\section{Introduction}

A tidal bundle is defined as the increment of either dune crossstratified beds (e.g., Boersma, 1969; Nio and Yang, 1991) or vertically stratified tidal beds (e.g., Dalrymple et al., 1991; Dalrymple, 2010), which is in each case deposited during a single dominant tidal phase, i.e., either during the flood tide or the ebb tide. Tidal bundle successions provide geologists with a plethora of information on the tidal flows that generated them, including how fast currents were flowing and the degree of local ebb-flood asymmetry (Martinius and Van den Berg, 2011), whether the tides were semi-diurnal or (less commonly) diurnal, and other phenomena such as diurnal inequality, neap-spring cyclicity, and fortnightly inequality. Neap-spring tidal cyclicities, fortnightly inequalities and tidal cycles of longer duration associated with differences

\footnotetext{
* Corresponding author.

E-mail address: tidalchoi@snu.ac.kr (K. Choi).
}

in the Earth's rotational and lunar orbital periodicities, are well documented from ancient tidal deposits (e.g., Yang and Nio, 1985; Kvale and Archer, 1991; Williams, 1991; Tirsgaard, 1993; Eriksson and Simpson, 2000; Tape et al., 2003; Longhitano, 2011; Longhitano et al., 2012; Legler et al., 2013; Reynaud et al., 2013; Abouessa et al., 2014). By contrast, although tidal bundles are a common feature in modern tidal environments (e.g., Dalrymple, 1984; Fenies and Tastet, 1998; Fenies et al., 1999; Flemming, 2012), neap-spring cycles and fortnightly inequalities in maximum tidal elevations have rarely been documented in cross-section (Visser, 1980; Boersma and Terwindt, 1981; Van den Berg et al., 2007).

The internal structure of tidal bundles is known to reflect both the asymmetry and the strength of tidal currents (De Mowbray and Visser, 1984; Nio and Yang, 1991). Variation of the strength of the subordinate current leads to a wide spectrum of structures, from entirely unidirectional cross-stratification to complex, bidirectional cross-stratification replete with reactivation surfaces (Boersma and Terwindt, 1981; De 
Mowbray and Visser, 1984; Van den Berg et al., 2007; Martinius and Van den Berg, 2011). Because tidal asymmetry varies with water depth in tidal channels, tidal bundles also provide information regarding tidal elevation (e.g., Martinius and Van den Berg, 2011). In particular, the nature of mud drapes with pause planes bracketing tidal bundles is commonly taken as a faithful indicator of subtidal versus intertidal deposition. Conventionally, if double mud-drapes bracket tidal bundles, subtidal deposition is assumed because the subtidal zone can experience both high- and low-tide slack-water periods, whereas if single mud drapes bracket tidal bundles, intertidal deposition is assumed because the intertidal zone only experience one slack-water period (high-tide slack water) per tidal cycle (Visser, 1980). However, there seem to be exceptions to this. Thus, Fenies et al. (1999), for example, documented double mud drapes in the intertidal zone that formed by the trapping of highly turbid water in dune troughs during falling tides. Also, in subtidal settings where tidal asymmetry is small, the subordinate current may erode the underlying mud drape, resulting in the generation of a single mud drape per tidal cycle (De Mowbray and Visser, 1984; Nio and Yang, 1991). Caution is therefore advised when inferring elevation within the tidal frame based on mud drapes alone. Although the internal structures of tidal bundles and associated hydrodynamic processes are described in detail by many authors (e.g., Boersma and Terwindt, 1981; Martinius and Van den Berg, 2011), existing case studies have mainly documented tidal bundles from channelized backbarrier mesotidal settings where tidal currents are generally rectilinear (Boersma and Terwindt, 1981).

The present study documents tidal dunes in the lower intertidal zone of an open-coast macrotidal environment in Gyeonggi Bay, Korea. The internal structures of the dunes reveal hierarchical tidal cycles preserved as tidal bundles-the first documented example of such features from an unbarred, macrotidal setting. The morphodynamics and hydrodynamics of the dunes are analyzed to elucidate the factors that controlled the temporal and spatial variability of the tidal bundle structures. A model for mud-drape deposition is proposed to help differentiate deposition in unconfined open-coast tidal settings (this study) from deposition in confined channelized tidal settings.

\section{Study area}

Gyeonggi Bay is a wide-mouthed, macrotidal embayment along the west coast of Korea (Fig. 1A). The outer part of the bay is occupied by large, NE-SW elongated tidal bars (100 km long and $30 \mathrm{~km}$ wide). In the inner part, the Han River splits into four delta distributary channels around bedrock islands before debouching into Gyeonggi Bay (Cummings et al., 2016). Wide, gently sloping open-coast tidal flats fringe the rocky coastlines of the islands and mainland near the mouth of the Han River. The Yeochari tidal flat is located on the southwestern side of Ganghwa Island in the northern Gyeonggi Bay (Fig. 1A, B). Bounded by two distributary channels of the Han River, the Jangbong and Sukmo channels, it stretches southwestward, reaching a maximum width of $6 \mathrm{~km}$ during spring low tides. The tidal flat has three distinct morphologic zones, an upper-intertidal zone, which has a convex-up profile; a middle-intertidal zone, which has a concave-toconvex profile intersected by small tidal creeks; and a lower-intertidal zone, where large tidal channels are present. The area of investigation is located in the lower intertidal zone (Fig. 1C). Tidal channels are narrow and highly sinuous in the middle intertidal zone, and become wider and straighter toward the lower intertidal zone. Flood-oriented and ebb-oriented dunes are present on the channel banks of the lower intertidal zone. Most of the dunes are asymmetric and lack smaller, superimposed dunes. Large compound dunes are locally found on the lower channel bank near the Jangbong Channel.

Tides are semidiurnal and have a distinct diurnal and fortnightly inequality of up to $1 \mathrm{~m}$ (Fig. 2). Tidal ranges are $9 \mathrm{~m}$ during spring tides and $6 \mathrm{~m}$ during neap tides. Tidal currents range from $0.8 \mathrm{~m} / \mathrm{s}$ during neap tides to over $1.5 \mathrm{~m} / \mathrm{s}$ during spring tides. They are flood-dominated on the tidal flats and ebb-dominated in the channel (Choi and Jo, 2015). Suspended-sediment concentrations reach up to $2.5 \mathrm{~g} / \mathrm{l}$ (Lee et al., 2013) and are greater during the ebb than during the flood (Choi and Jo, 2015). Significant wave heights reach $1.2 \mathrm{~m}$ during winter storms when winds blow from the northwest and during summer typhoons when south and southeast winds blow, but are lower than $0.3 \mathrm{~m}$ during fairweather conditions (Choi and Jo, 2015). Precipitation is seasonal with highest rainfalls during the summer season (July to September), accounting for about two-thirds of the mean annual precipitation of 1300 mm (KMA, 2013).

\section{Materials and methods}

High-precision morphologic profiles were acquired seven times from October 2014 to August 2015 along three transects $(A B, C D$, and $\mathrm{EF}$ ) on foot at low tide with RTK-GPS positioning with a $10 \mathrm{~mm}$ horizontal and $20 \mathrm{~mm}$ vertical accuracy (Figs. 1,2). Transects AB and CD run parallel to the channel and are 120 and $140 \mathrm{~m}$ long, respectively. They cross the dunes on the upper and the lower bank, respectively. Transect $\mathrm{EF}$ is oriented perpendicular to the channel and is $150 \mathrm{~m}$ long. Transects were repeatedly measured at one-day intervals to calculate dune migration rates. GPS positions were recorded at 3-5 m intervals along the transects. Elevations were corrected relative to the mean sea level (Incheon Datum). Current profiles and directions were measured at two locations representing the upper (A1 in Fig. 1C) and the lower bank (A2 in Fig. 1C) using Nortek AQUADOPP current profilers (2 $\mathrm{MHz}$ ) equipped with optical back-scatter (OBS) sensors. Current profilers were moored from 8 to 25 January in 2015. The elevations of the AQUADOPP sensors were $-2.2 \mathrm{~m}$ for $\mathrm{A} 1$ and $-3.6 \mathrm{~m}$ for $\mathrm{A} 2$, which is approximately $0.8 \mathrm{~m}$ above the tidal flat surface. The blanking distance was $0.2 \mathrm{~m}$ for both AQUADOPPs. Current data were sampled every $5 \mathrm{~min}$ in burst mode for $3 \mathrm{~min}$ with a ping rate of $1 \mathrm{~s}$. Suspended-sediment concentrations (SSCs) were measured by the OBSs attached to the AQUADOPP profilers using a sampling rate of $30 \mathrm{~s}$. A series of water samples was taken during the late ebb stage and the early flood phase. These were subsequently filtered through $0.45 \mu \mathrm{m}$ Millipore membranes, with the residues being dried for $3 \mathrm{~h}$ at $90{ }^{\circ} \mathrm{C}$ in an oven and then weighed to calculate SSCs. The SSCs of the water samples were used to convert nephelometric turbidity units (NTUs) measured by the OBSs to sediment concentrations $(\mathrm{g} / \mathrm{l})$.

A total of 15 trenches were excavated in the tidal dune field of the western bank of the main channel. The trenches range from 5 to $16 \mathrm{~m}$ in length and 0.3 to $0.8 \mathrm{~m}$ in depth and, in each case, cover the distance of one dune wavelength. The exposed tidal bundles along two trench sections (T1 and T2 in Fig. 1D) were documented and described in detail. The thicknesses of the tidal bundles (measured normal to cross-stratification) were extracted from photographs. A fast Fourier transform (FFT) program was used to calculate a periodogram of the tidal bundle thickness data from T1. Undisturbed core slabs were taken from the trenches using two types of stainless steel can corer $(60 \mathrm{~cm} \times 10 \mathrm{~cm} \times 2 \mathrm{~cm}, 80 \mathrm{~cm} \times 10 \mathrm{~cm} \times 2 \mathrm{~cm})$. Relief peels were made from the core slabs using epoxy and cheese cloth to preserve sedimentary structures for detailed analysis. Grain-size analysis was conducted using conventional sieve and pipette methods. Orientations and dip angles of dunes and bedding surfaces were measured by means of a compass fitted with a clinometer (Suunto Tandem 360PC).

\section{Results}

\subsection{Dune occurrence and morphology}

Dunes are present in the lower intertidal zone on the western bank of the main channel (Figs. 3, 4). This channel is $300 \mathrm{~m}$ wide and $5 \mathrm{~m}$ deep along transect EF (Fig. 3B), and is bordered by muddy tidal flats (Choi and Jo, 2015). During spring high tides, when the entire tidal flat becomes submerged, the water depth above the channel thalweg 

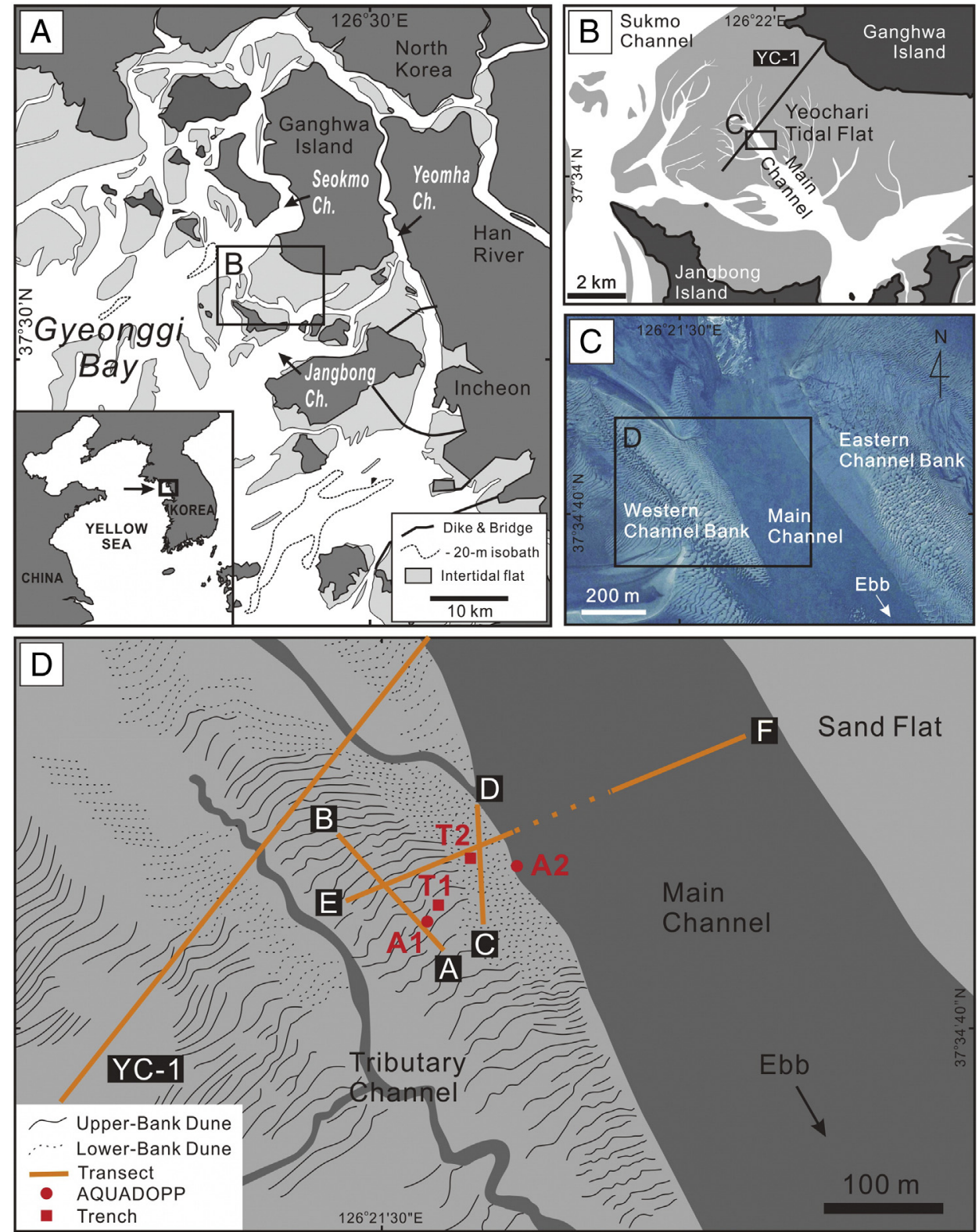

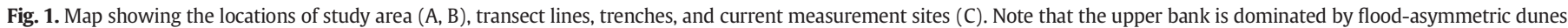
whereas the lower bank is occupied by ebb-asymmetric dunes (C).

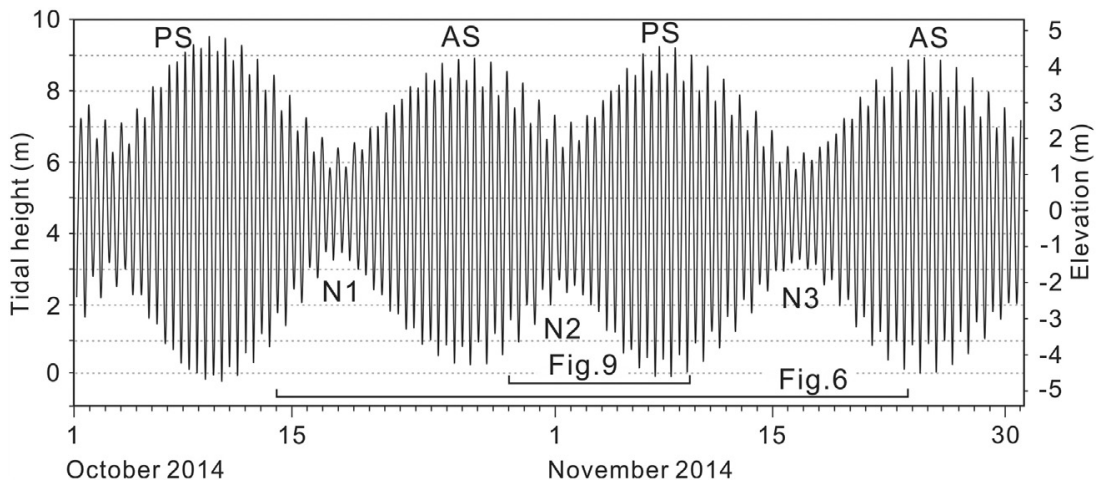

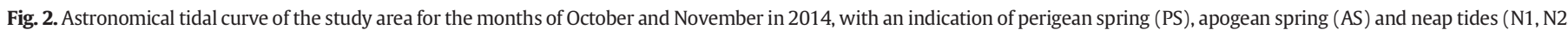
N3). See Figs. 6, 9 for the tidal bundles formed during the bracketed intervals. 

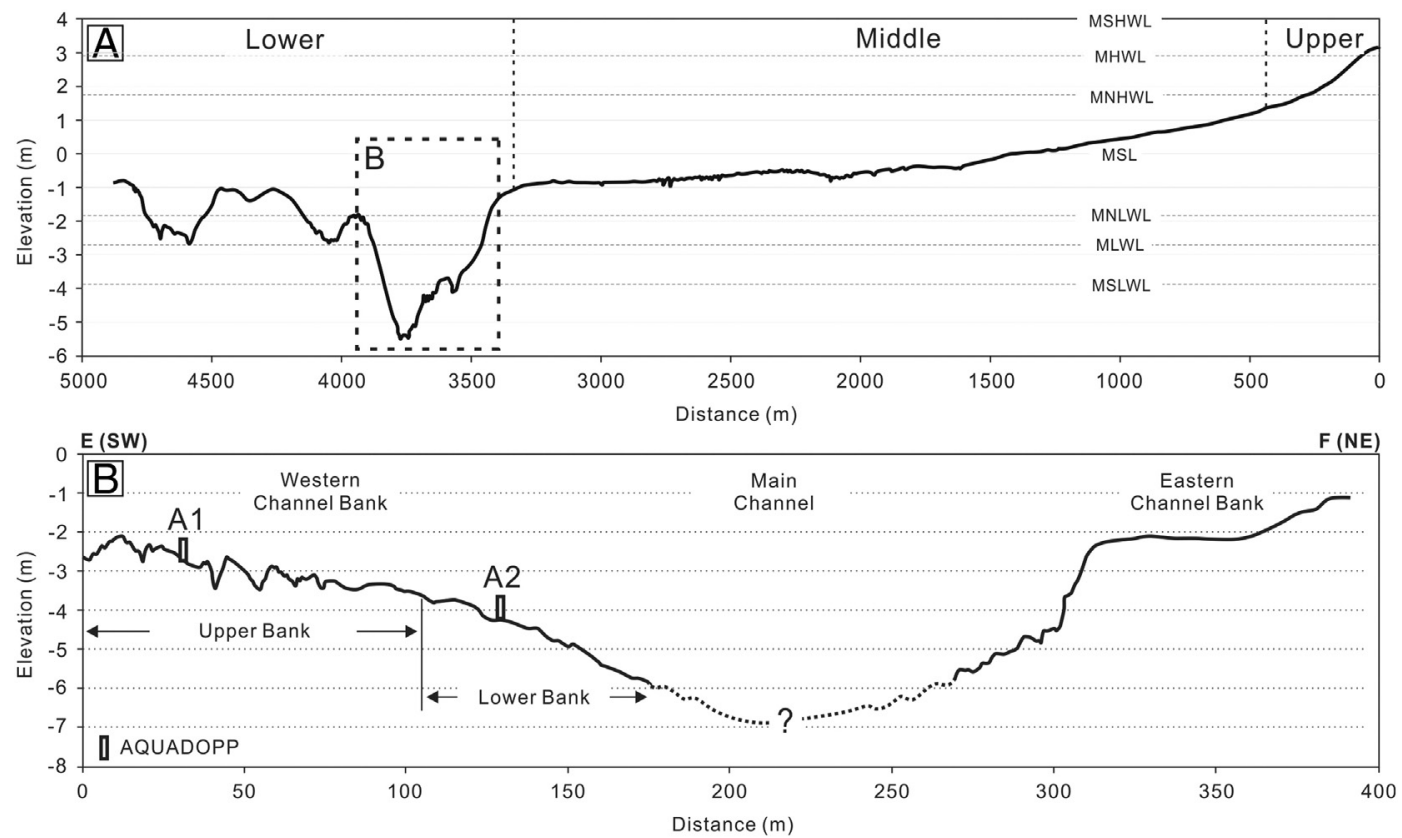

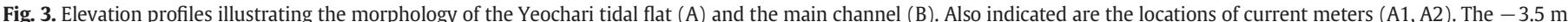

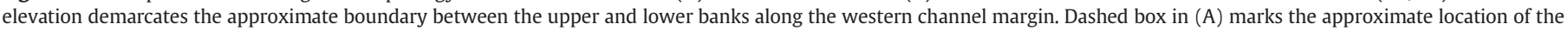

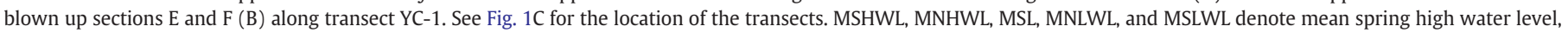
mean neap high water level, mean sea level, mean neap low water level, and mean spring low water level, respectively.

increases up to $9 \mathrm{~m}$. Dunes are mainly present between mean spring and mean neap low-water levels, at elevations of -2 and $-5 \mathrm{~m}$ (Fig. 3A). They lack superimposed dunes (i.e., they are simple dunes sensu Ashley, 1990), and consequently have no internal master bedding surfaces.

On the upper bank, dunes occur at elevations between -2 and $-3.5 \mathrm{~m}$ and are flood asymmetric (Figs. 4A, 5A). Dune heights and wavelengths range from 20 to $60 \mathrm{~cm}$ and 10 to $20 \mathrm{~m}$, respectively. The dunes become less pronounced during winter, maintaining similar wavelengths but developing smaller heights. Dune crests are largely straight and oriented northeast-southwest. Dip angles of the steeper lee faces vary from $16^{\circ}$ to $21^{\circ}$, whereas those of stoss faces are mainly less than $13^{\circ}$. The top of the dunes are smooth and devoid of smallscale bedforms. Ebb-directed current ripples, including ladder-back ripples, are present in the dune troughs, in addition to thin (1-2 mm) mud drapes (Fig. 4A). Rounded mud pebbles and tiny shell fragments are sparsely distributed in the dune troughs. The dunes on the upper bank migrate as fast as $2 \mathrm{~m} /$ day (Fig. 5C, D). They consist of mostly fine to medium sand (3.5-3.9 phi; 0.067-0.088 $\mathrm{mm}$ ), with sand contents reaching nearly $90 \%$ and the remainder comprising mud $(<63 \mu \mathrm{m})$.

On the lower bank, dunes occur at elevations of -3.5 and $-5 \mathrm{~m}$, and are symmetric to ebb asymmetric (Figs. 4B, 5B). The dune heights and wavelengths vary from 10 to $35 \mathrm{~cm}$ and from 5 to $10 \mathrm{~m}$, respectively. The dunes disappear during winter, and the lower bank develops a featureless profile. The dune crests are largely straight and mainly oriented east-west. However, dune crests at the transition between lower and upper bank dunes, roughly corresponding to $-3.5 \mathrm{~m}$ below mean sea level, are highly sinuous. The dip angles of the ebb-dipping lee faces vary between $15^{\circ}$ and $23^{\circ}$, whereas those of the stoss faces are less than $10^{\circ}$. Ebb-directed current ripples are common in dune troughs (Fig. 4B), these being larger than those on the dunes at higher elevations. Mud drapes are more widely distributed within the dune troughs (Fig. 4B). Mud pebbles and shell fragments are more common than on the upper bank. Older, semi-consolidated mud-flat deposits are exposed locally in dune troughs (Fig. 4E, F). The dunes consist mostly of fine to medium sand (3.4-3.9 phi; 0.067-0.095 $\mathrm{mm}$ ), with the sand content in the thicker and sandier bundles reaching nearly $90 \%$ and the remainder comprising mud $(<63 \mu \mathrm{m}$ ). The sand content drops to around $50 \%$ in the muddier intervals, where silt contents typically exceed $35 \%$ and mean grain sizes vary from $4.7-5.4$ phi $(0.024-0.038 \mathrm{~mm})$.

\subsection{Internal structure of tidal bundles}

The dunes on the upper bank have small ebb caps and, in crosssection, display flood-oriented cross-bedding with thin (1-2 mm) and discontinuous mud drapes (Figs. 6, 7). The cross-beds are tabular with tangential basal contacts. The cross-bed dips range from $22^{\circ}$ to $35.4^{\circ}$. Ebb-oriented backflow ripples are absent in the bottomset of the flood-oriented cross-beds. Gently-sloping planar lamination and descending flood-directed subcritical climbing ripples are present below the cross-beds (Fig. 7A, B); these are a common feature of the thicker and sandier bundles. The erosional and irregular lower contacts of the flood-directed climbing ripples truncate underlying non-climbing, ebb-directed ripples, thereby defining reactivation surfaces generated during subordinate ebb tides (e.g., Visser, 1980). The ebb-oriented ripple cross-lamination has sharp contacts with underlying cross-beds. A tidal bundle is defined as the interval between the top surfaces of the neighboring ebb-oriented ripple cross-laminations. The plot showing the variation in thickness of tidal bundles from the upper-bank dunes, measured perpendicular to the dip of dune foresets, is illustrated in Fig. 8A. Mud pebbles and shell fragments are sparsely distributed within the cross-bedding, which is not developed in the muddier and thinner bundles (Fig. 7C, D). In these intervals, low-angle $\left(10.2^{\circ}-\right.$ $11.9^{\circ}$ ) parallel lamination and current ripple cross-lamination are dominant. Ripple cross-lamination is bidirectional and includes herringbone cross-laminations. Bioturbation is rare, but escape burrows are observed locally (Fig. 7C, D), which indicates rapid sedimentation.

The dunes on the lower bank have large ebb caps and display floodoriented cross-beds with thick (5-15 mm) mud drapes (Figs. 9, 10). The dip angles of the cross-beds are much more gentle $\left(11.2^{\circ}-25.6^{\circ}\right)$ than those in the dunes on the upper bank. Backflow ripples are not observed in the bottomset of the cross-beds. Planar lamination and descending subcritical climbing ripples are developed below the cross-beddings (Fig. 10A, B), which is a common feature in the sandier and thicker 

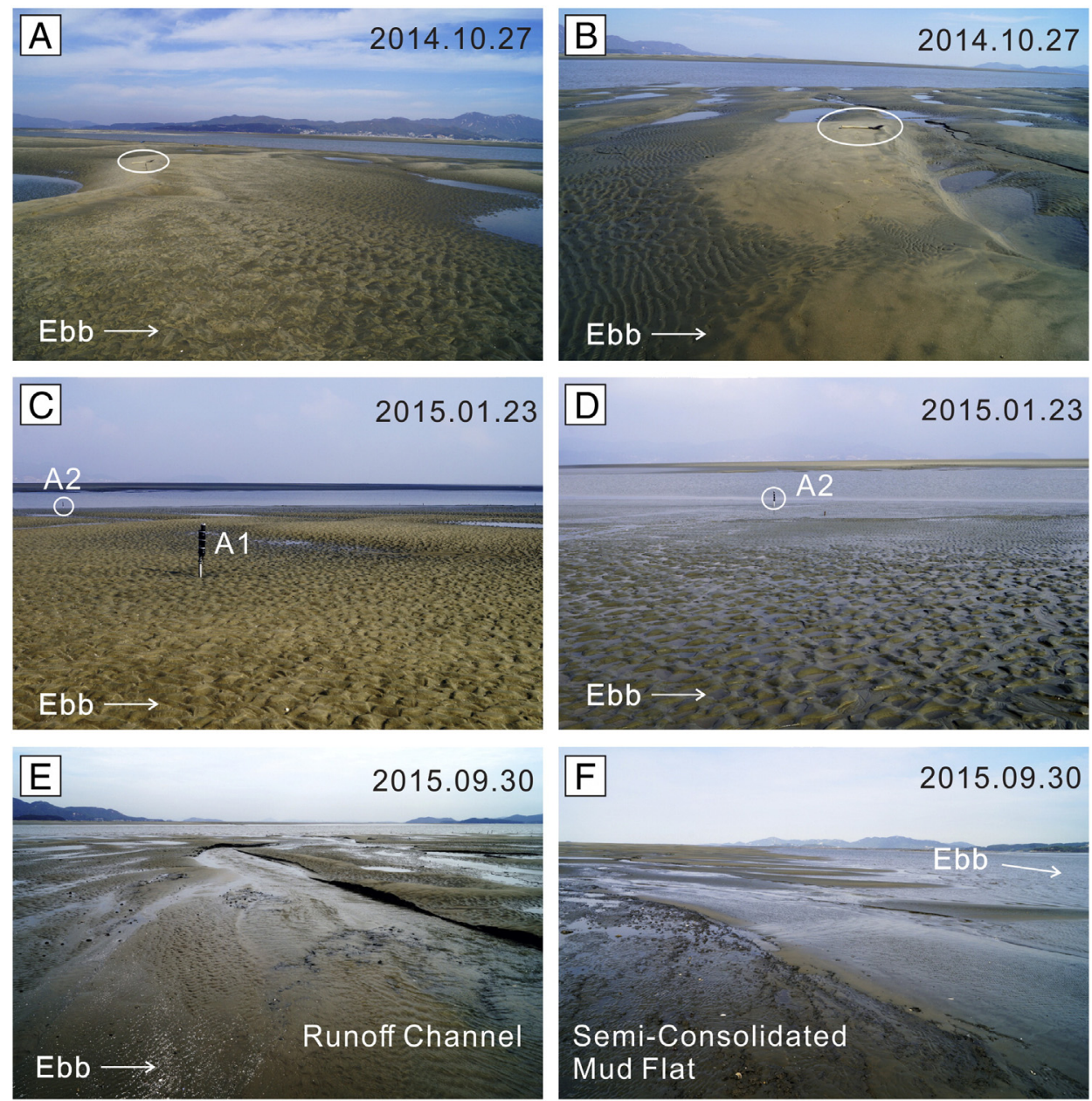

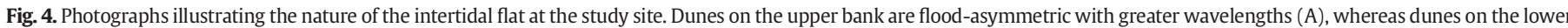

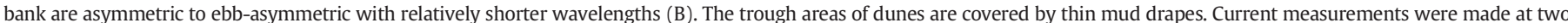

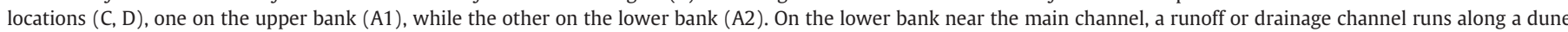

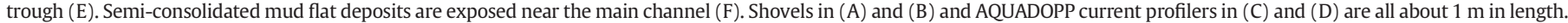
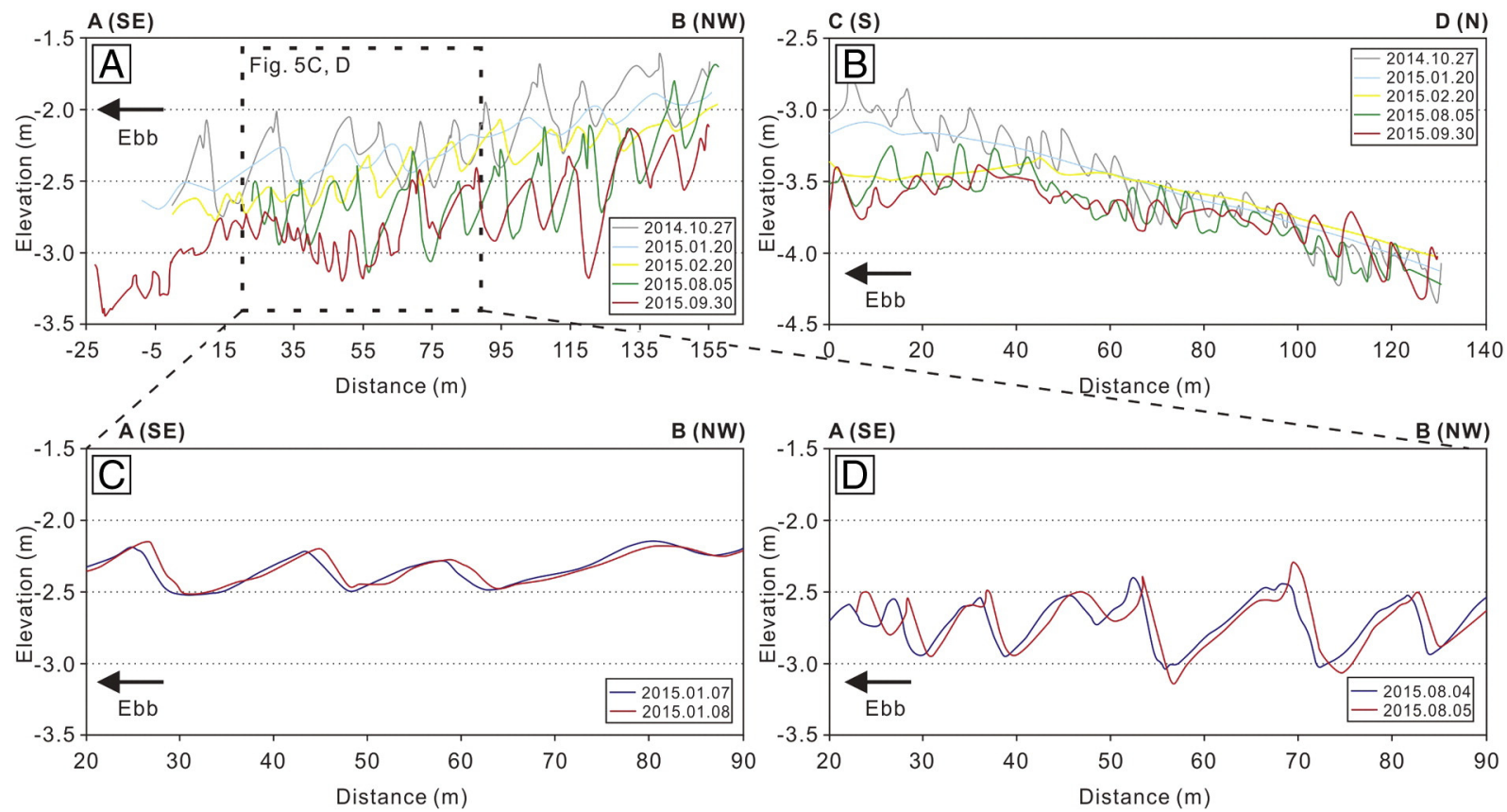

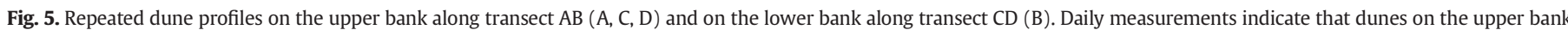
(C, D) migrate in the flood direction. Note the contrasting winter (C) and summer (D) dune profiles. See Fig. 1C for the location of the transects. 

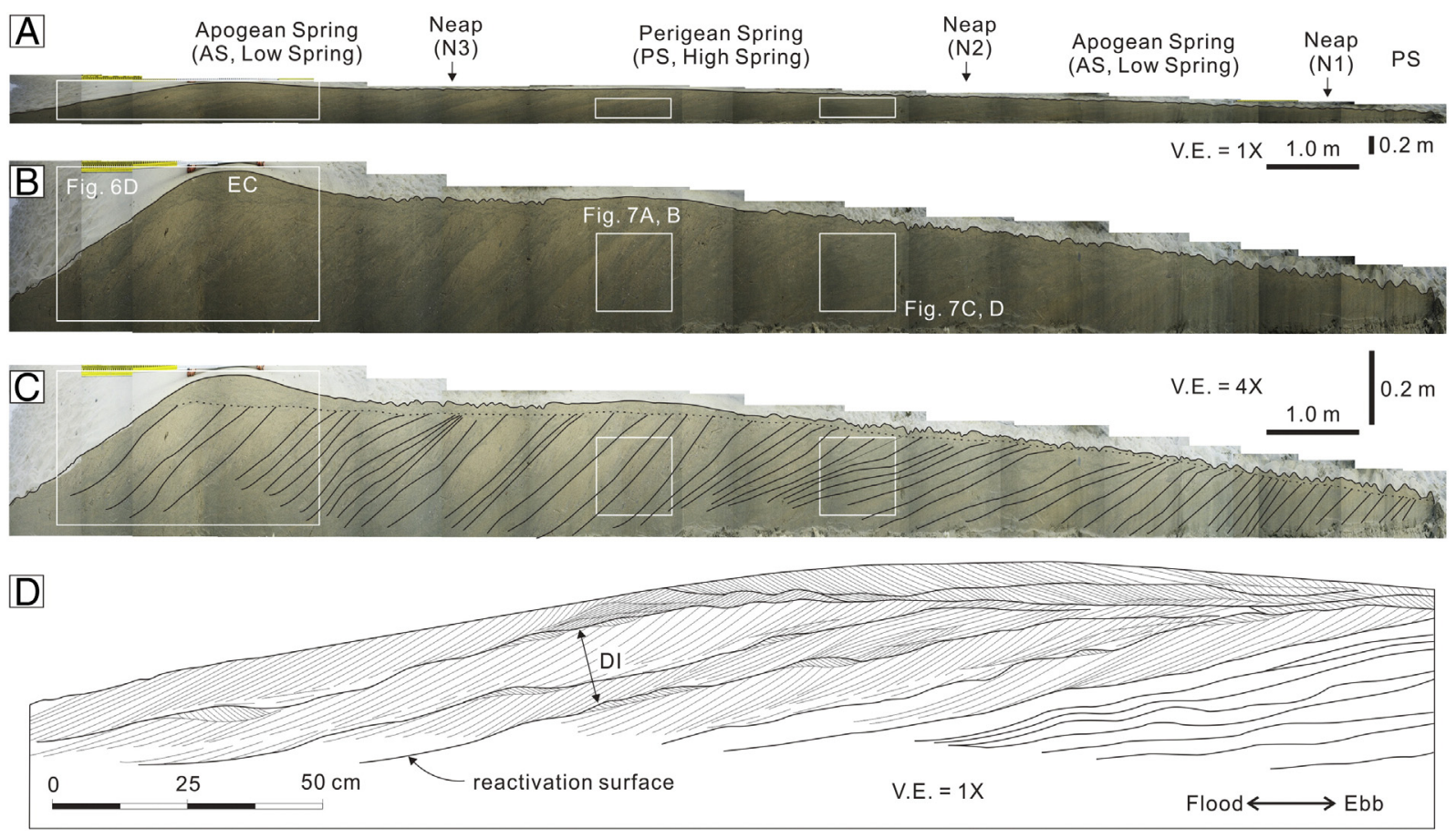

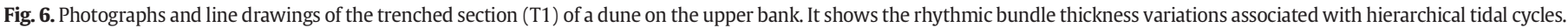

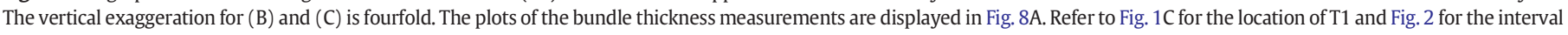
of the tidal curve during which the bundle structures formed. EC and DI denote ebb cap and diurnal inequality, respectively.

bundles. Ebb-oriented current ripples are larger and more continuous than those in the upper-bank dunes, constituting the so-called set climbers. The ebb-oriented ripples are overlain by thick mud drapes, their thickest portions occurring in the ripple troughs. The mud drapes formed during spring tides are thicker than those formed during neap tides (Fig. 11), being stratified to cross-stratified and dipping upslope (Fig. 11A, B). They consist of silt and very fine sand (Fig. 11C, D). The top of the mud drapes comprise reactivation surfaces generated by subordinate ebb currents (e.g., Martinius and Van den Berg, 2011). Mud pebbles and shell fragments are rarely visible within the cross-bedding. Brinkpoints are observed within the ebb-oriented cross-beddings of the ebb caps. Herringbone cross-lamination is well developed in the muddier intervals where cross-beds are thinner (Fig. 10C, D).

\subsection{Tidal cyclicities}

The visual observation of vertical sections exposed along trenches in the dunes on the upper and lower banks indicates that bundle thicknesses range between 2 and $15 \mathrm{~cm}$, and show rhythmic variations (Fig. 8A). Most notable thickness variations are (1) the alternation of thick and thin bundles within a bundle package, (2) gradual increase and decrease in the thickness of bundles in a package consisting of 20-24 bundles, and (3) the alternation of thick and thin bundle packages. The alternations from thick to thin bundles represent the diurnal inequality of the semidiurnal tides (De Boer et al., 1989; Kvale and Archer, 1991). In other words, thicker and thinner bundles represent successive higher and lower tides of a day, respectively. Cyclic bundle thickness variations over 20 bundles are the product of spring-neap tidal cycles, i.e., synodic tidal cycles (Boersma and Terwindt, 1981; Nio and Yang, 1991), with thicker, steeper and coarser-grained bundles deposited during spring tides, and thinner, gentler and finer-grained bundles deposited during neap tides. The alternations of thick and thin bundle packages represent successive higher and lower spring tides of a month, i.e., anomalistic tidal cycles (Boersma and Terwindt, 1981).
The FFT (fast Fourier transform) analysis on the tidal bundle thickness data suggests that the dominant spectral peaks (periods of 2.1, 22 and 47 bundles) correspond to the diurnal inequality in tidal range, the neap-spring cycle, and the fortnightly inequality in tidal range, respectively (Fig. 8B).

\subsection{Hydrodynamics}

Tides are semidiurnal, with a distinct diurnal inequality of up to $1 \mathrm{~m}$ (Figs. 12, 13). The upper bank is flood-dominated (Fig. 12): the peak flood and ebb current speeds are $0.59 \mathrm{~m} / \mathrm{s}$ (neap) to $1.4 \mathrm{~m} / \mathrm{s}$ (spring) and $0.38 \mathrm{~m} / \mathrm{s}$ (neap) to $0.72 \mathrm{~m} / \mathrm{s}$ (spring), respectively (Fig. 12). By contrast, the lower bank is ebb-dominated (Fig. 13): the peak flood and ebb current speeds are $0.69 \mathrm{~m} / \mathrm{s}$ (neap) to $1.47 \mathrm{~m} / \mathrm{s}$ (spring) and $0.93 \mathrm{~m} / \mathrm{s}$ (neap) to $1.59 \mathrm{~m} / \mathrm{s}$ (spring), respectively. The current speeds during peak spring high tides are $0.24 \mathrm{~m} / \mathrm{s}$ over the upper bank (Fig. 12B, D) and $0.16 \mathrm{~m} / \mathrm{s}$ over the lower bank (Fig. 13B, D). The current speeds during peak neap high tides are less than $0.1 \mathrm{~m} / \mathrm{s}$ over the upper bank (Fig. 12A, C) and nearly zero over the lower bank (Fig. 13A, C). Tidal asymmetry is greater over the lower bank than the upper bank, being particularly pronounced during spring tides.

Tidal current speeds are nearly uniform in the water column at any given time, except during spring high tides when the surface currents are about $0.1-0.2 \mathrm{~m} / \mathrm{s}$ faster than at the bottom. The tidal currents flow in a counterclockwise direction, from $320^{\circ}$ to $340^{\circ}$ during the peak flood to $140^{\circ}-160^{\circ}$ during the peak ebb (Figs. $12 \mathrm{~A}, \mathrm{~B}, 13 \mathrm{~A}, \mathrm{~B}$ ). A temporary clockwise rotation of tidal currents is observed just before the tide reaches its maximum elevation. Minimum current speeds occur $1.5 \mathrm{~h}$ after tides approach the maximum water depth when current directions change rapidly from $290^{\circ}$ to $170^{\circ}$ over the upper bank and from $320^{\circ}$ to $200^{\circ}$ over the lower bank (Figs. 12A, B, 13A, B). There is no slack-water period around peak high tide, except over the lower bank during neap tides. Distinct flood-current surges occur at $0 \mathrm{~m}$ elevation over the lower and upper banks during spring tides (Figs. 12B, 13B). Distinct ebb-current peaks occur around $-1 \mathrm{~m}$ elevation 

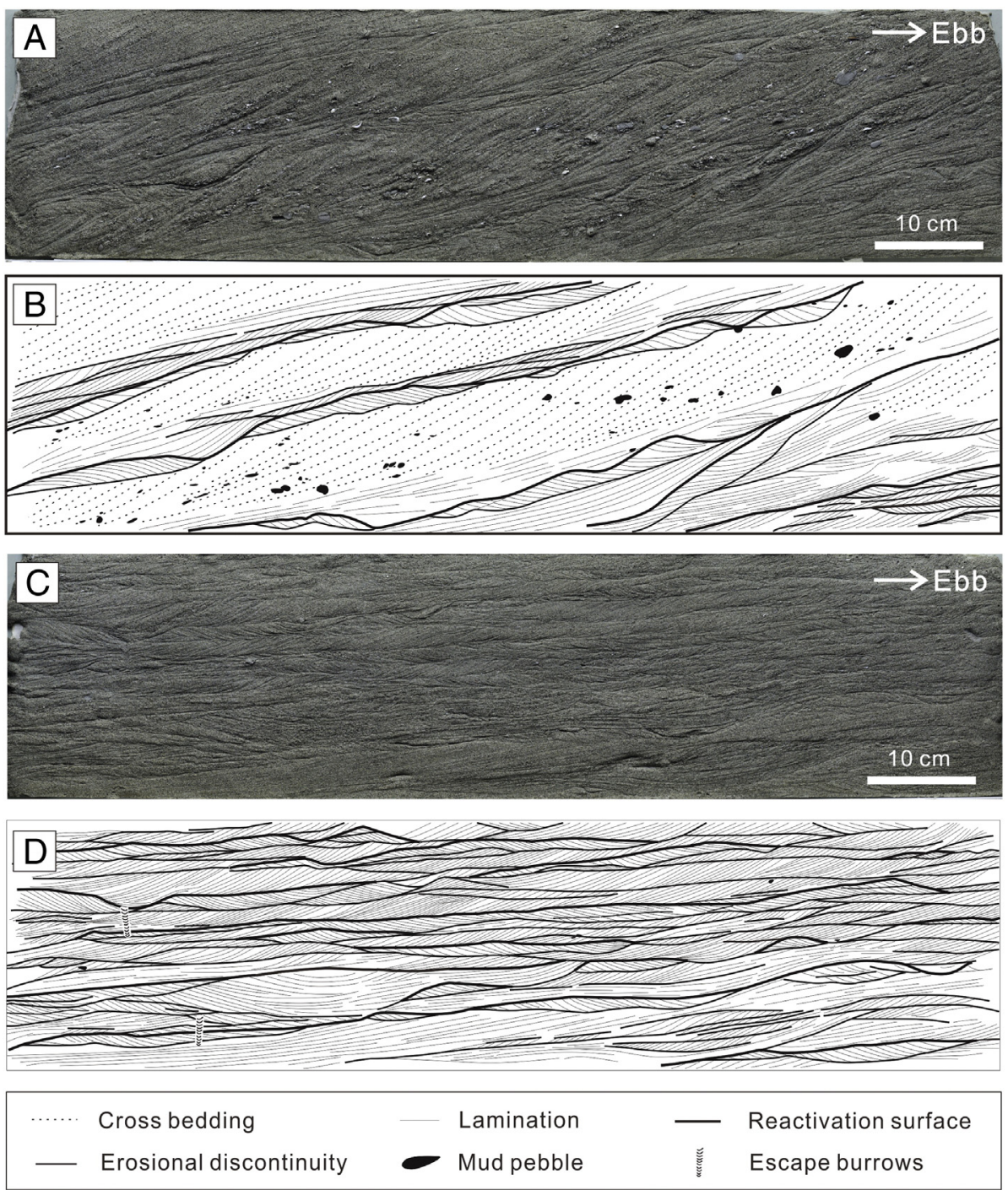

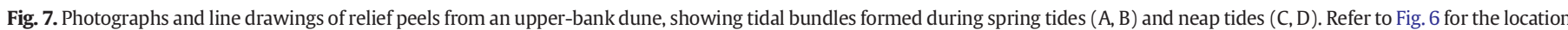
of photographs.

over the lower bank during spring tides. Ebb current peaks are less well defined over the channel bank. The difference in the water elevation at which peak velocities of flood and ebb currents occur, and on the basis of which the velocity peak asymmetry is defined (e.g., Fagherazzi et al.,
2008), is about $1 \mathrm{~m}$ on the lower bank and less than $0.5 \mathrm{~m}$ on the upper bank.

Suspended-sediment concentrations (SSCs) remain less than $300 \mathrm{mg} / \mathrm{l}$ during spring tides, except during peak ebb current stages
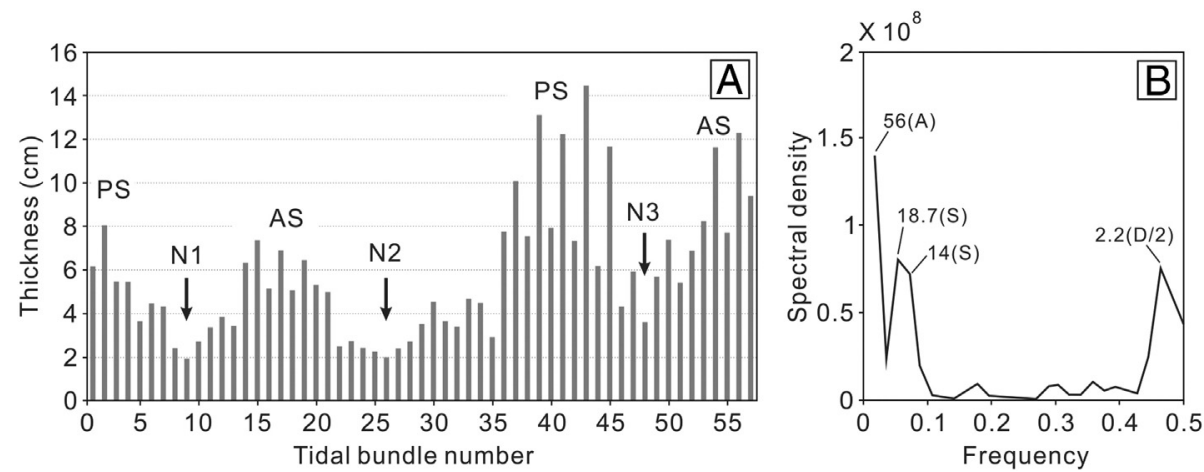

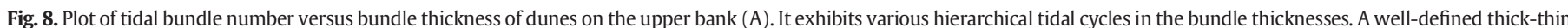

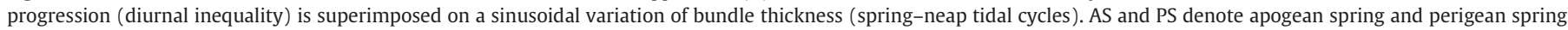

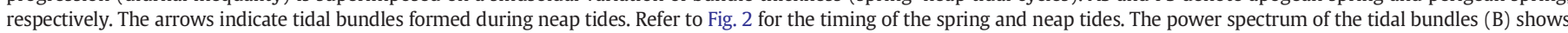
spectral peaks and periods associated with hierarchical tidal cycles. A, S, and D/2 denote the anomalistic month, half synodic month, and the semidiurnal signals, respectively. 


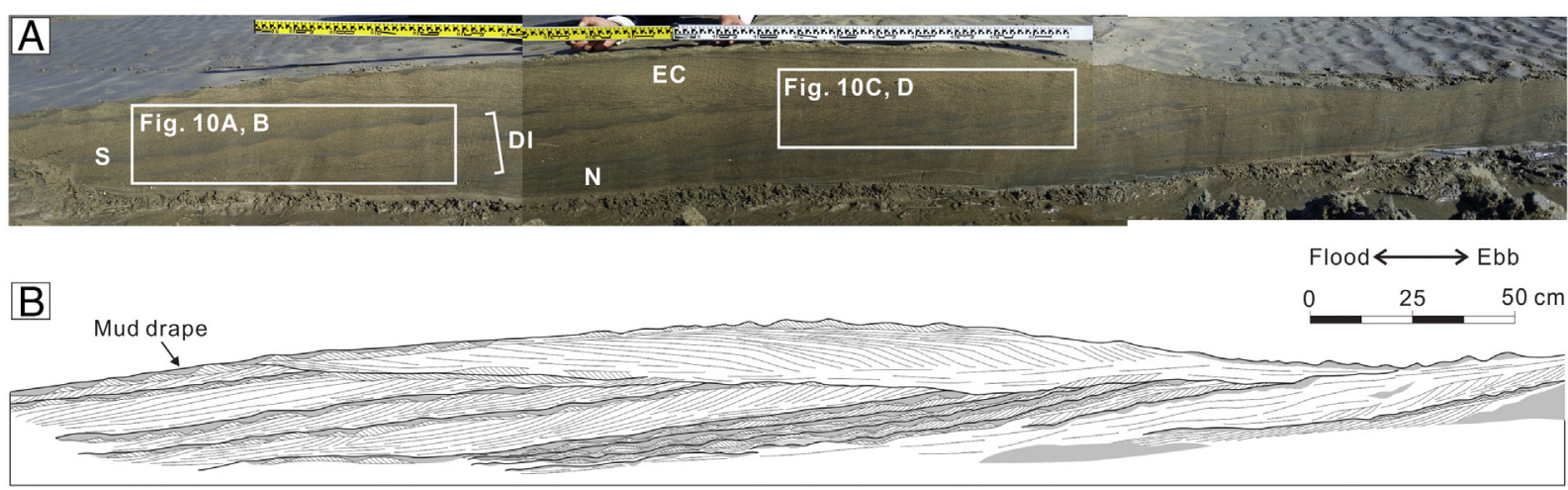

Fig. 9. Photograph showing a trenched section (T2) of a dune on the lower bank (A). The line drawing of the trenched section (B) depicts spring (S) and neap (N) stage bundles and the diurnal inequality (DI). Refer to Fig. 1C for the location of T2 and Fig. 2 for the interval of the tidal curve during which the bundle structures formed.

when the SSCs increase up to $900 \mathrm{mg} / \mathrm{l}$ on the lower bank (Fig. 13F) and up to $400 \mathrm{mg} / \mathrm{l}$ on the upper bank (Fig. 12F). The SSCs during neap tides are below $100 \mathrm{mg} / \mathrm{l}$. Occasionally SSCs increase up to $300 \mathrm{mg} / \mathrm{l}$ during neap tides (e.g., on Jan 17, 2015), which indicates the presence of waves (Figs. 12F, 13F). Contrary to the peak ebb currents, the increase in SSCs observed during the peak flood currents is less pronounced. There is no significant drop in SSCs around the peak high tides.

\section{Discussion}

\subsection{Factors controlling the internal structures of tidal bundles}

In the study area, the tidal bundle structures demonstrate rhythmic thickness variations similar to those of hierarchical tidal cyclicities. Because bedload sediment transport is proportional to current speed
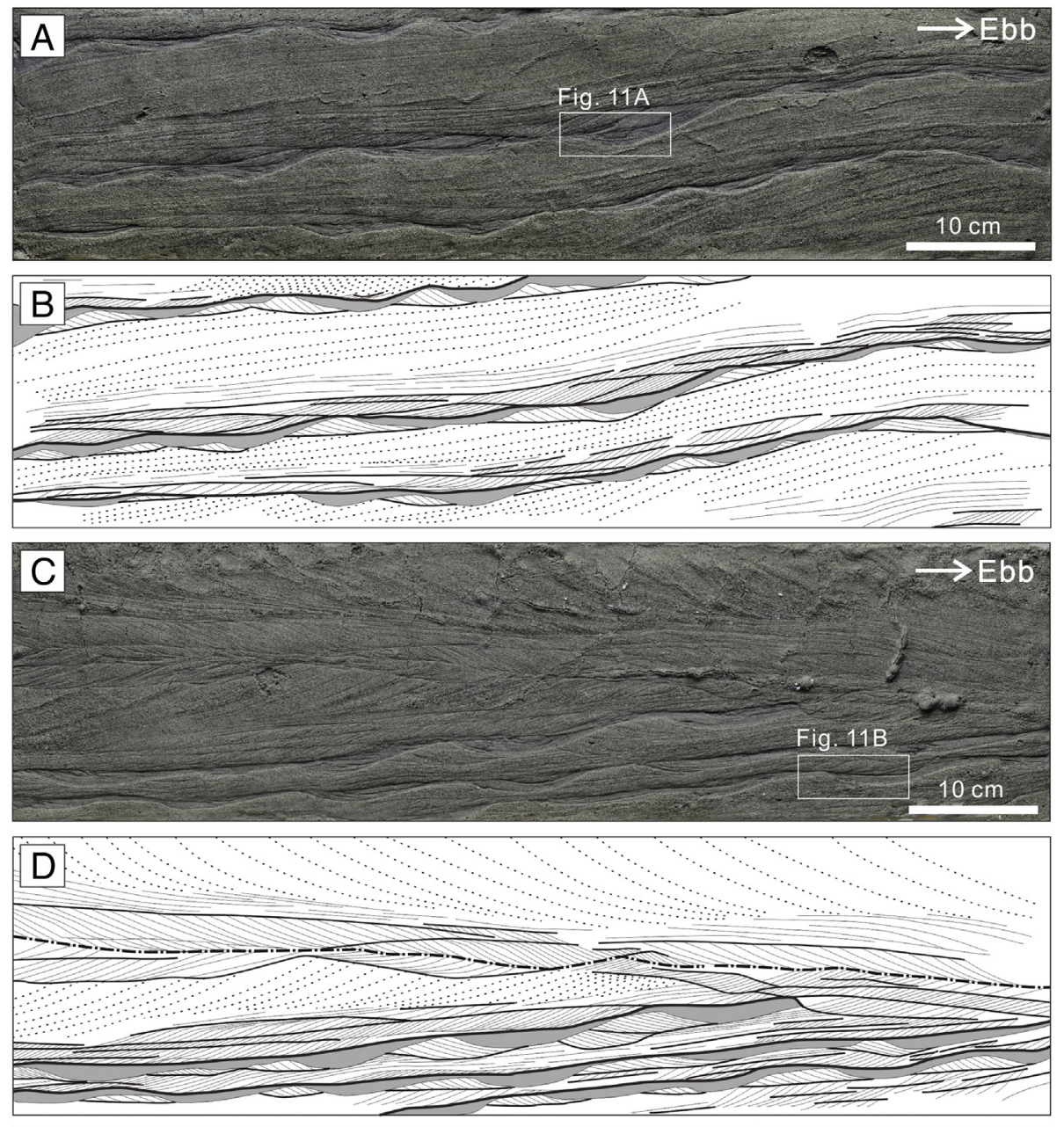

\begin{tabular}{|lll|}
\hline$\ldots . . .$. Cross bedding & Lamination & - Reactivation surface \\
& Erosional discontinuity & Mud drapes
\end{tabular}

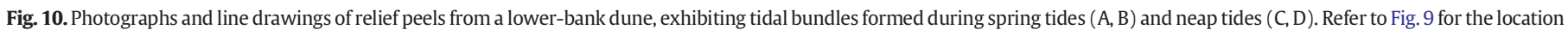
of photographs. 

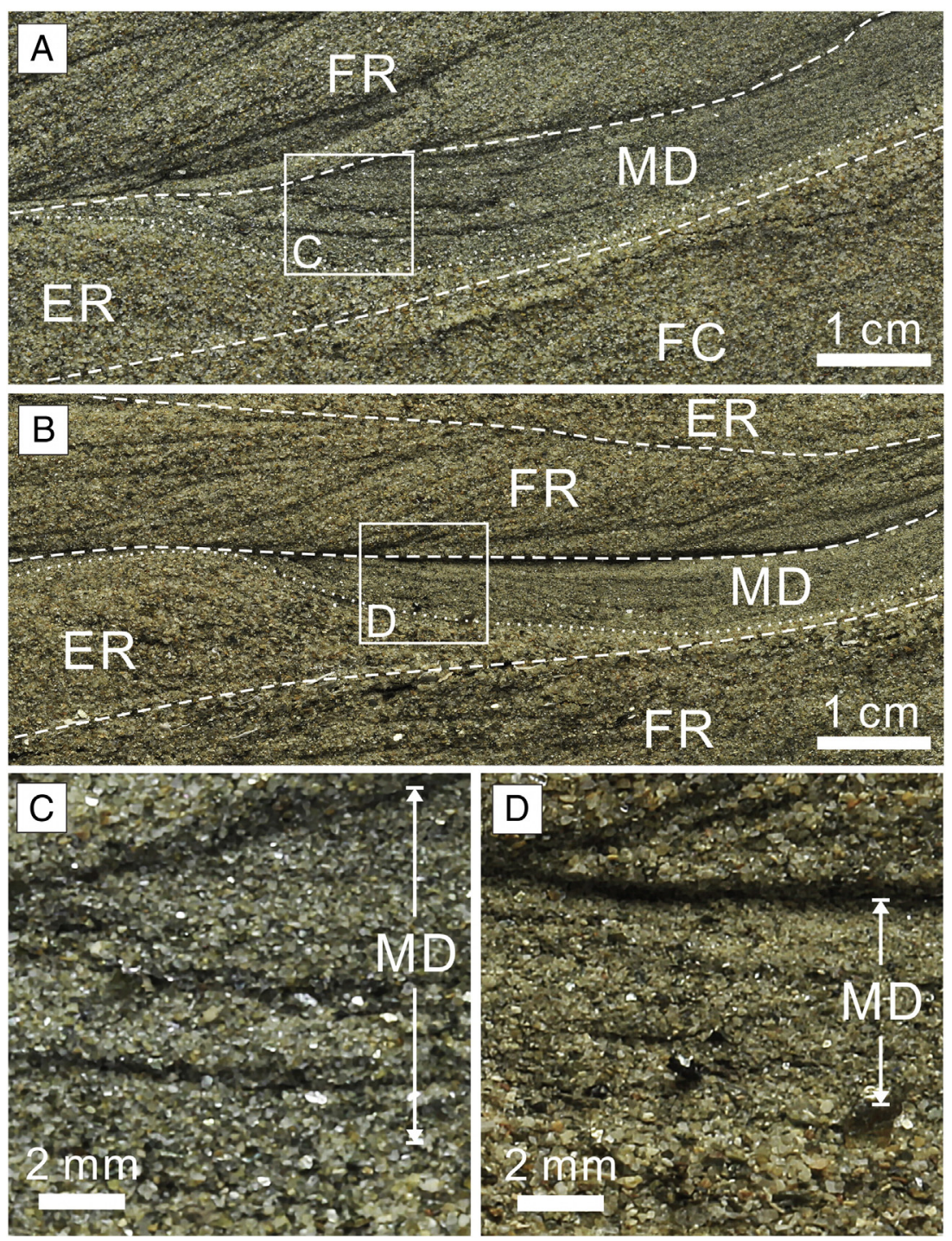

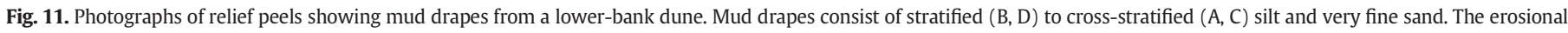

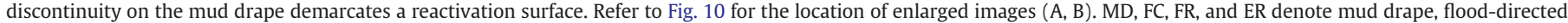
cross-beds, flood-current ripples, and ebb-current ripples, respectively.

(Dalrymple and Rhodes, 1995), well-defined tidal rhythmicities in the tidal bundle structures indicate that dune migration is driven mainly by tidal currents uniform in direction (e.g., Boersma and Terwindt, 1981). The dip angles of cross-stratification of the tidal bundles gradually increase toward spring tides, reflecting the increase in flow strength and water depth toward spring tides (Boersma and Terwindt, 1981; Dalrymple and Rhodes, 1995). Longer tidal cycles such as spring-neap cyclicities and fortnightly inequalities are better preserved in the upper-bank dunes, where time-velocity asymmetry is pronounced. In contrast, the longest sequence recognizable in the lower-bank dunes is half a neap-spring cycle, where time-velocity is much reduced and the shorter tidal cycle record relates to the relatively shorter wavelength of the dunes. The small time-velocity asymmetry with the presence of strong subordinate currents flowing over the lower bank appears to limit the growth of dune wavelength (e.g., Dalrymple and Rhodes, 1995).

Tidal bundles formed during spring tides display flood-directed cross-beddings with minor occurrences of ebb-directed ripples, whereas those formed during neap tides are characterized by bidirectional ripples (Fig. 14A, C, E, G, I). The temporal variation of the tidal bundle structures reflects the time-velocity asymmetry of the tidal currents, which increase toward spring tides and decrease toward neap tides.
Spring-tide bundles exhibit a vertical succession from climbing ripples at the base passing upward into parallel lamination and flood-directed cross-stratification, which is interpreted to represent bedload transport by accelerating flood currents with weak vortex development (Boersma and Terwindt, 1981; Martinius and Van den Berg, 2011). Backflow ripples are not observed in the bottomset of the flood-directed crossbeds, which implies that backflows in the dune troughs during peak flood currents are incapable of forming ripples (e.g., Martinius and Van den Berg, 2011). Unlike flood currents that maintain their speed above threshold for bedload transport long enough to produce crossbeds, ebb currents with speeds sufficiently high $(>0.6 \mathrm{~m} / \mathrm{s})$ to promote a dune-forming process last mostly less than $2 \mathrm{~h}$ over the upper bank. The duration of ebb currents is apparently insufficient to reverse the dune profile and, hence, to produce ebb-directed cross-beds (e.g., Terwindt and Brouwer, 1986; Dalrymple and Rhodes, 1995). This explains the paucity of ebb-directed cross-beds in the upperbank dunes despite the presence of strong ebb currents with speeds $>0.9 \mathrm{~m} / \mathrm{s}$.

Small time-velocity asymmetry and weak current speeds below the threshold of dune existence lead to the formation of bidirectional ripples and numerous reactivation surfaces in the neap-tide bundles. Gently sloping reactivation surfaces and larger ebb caps in the lower-bank dunes 

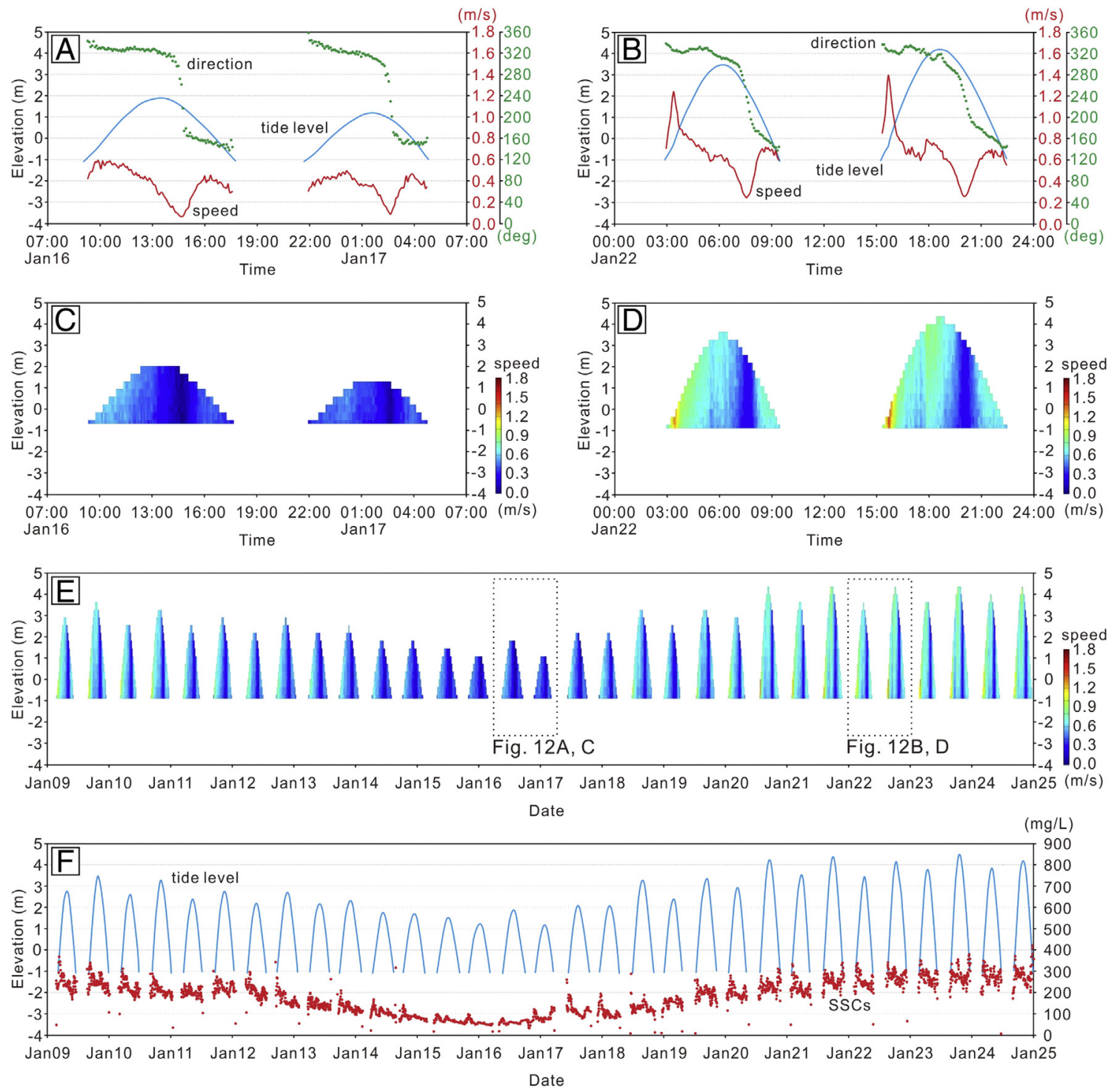

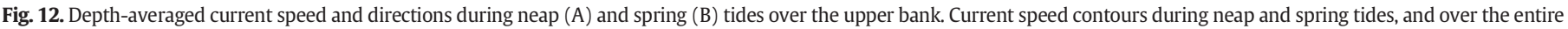

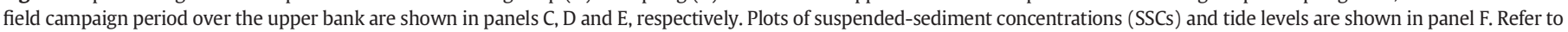
Fig. $1 \mathrm{C}$ for the location of the measurements (A1).

suggest that tidal asymmetry decreases at the lower topographic elevation in the channel (Fig. 14B, D, F, H, J). The current measurements indicate that the peak ebb current speeds on the upper bank are greater than those on the lower bank, which is in stark contrast with the flooddominance of the upper bank. In fact, the ebb caps in the lower-bank dunes display fully developed vortex structures, including ebb-directed cross-beds (e.g., Boersma and Terwindt, 1981), indicating that appreciable bedload transport occurs during ebb tides. However, despite the higher ebb-current speeds, their relatively shorter duration above the threshold for bedload transport of fine to medium sands leads to the preferential preservation of flood-directed cross-beds in the lower-bank dunes. Large ebb caps are subject to erosion during subsequent flood currents (Fig. 14H, J) and, as a consequence, have a low preservation potential. The current data indicate that the ebb current peaks occur at water elevations that are about $1 \mathrm{~m}$ lower than those of the flood current peaks. The magnitude of the velocity peak asymmetry, which refers to the difference in the water elevation of the flood and ebb current peaks, is more pronounced than that of the channelized backbarrier settings (e.g., Bayliss-Smith et al., 1979; Pethick, 1980; Boersma and Terwindt, 1981; Fenies et al., 1999). Pronounced velocity peak asymmetry combined with time-velocity asymmetry seems to facilitate preferential preservation of flood-directed cross-beds in the intertidal zone of opencoast macrotidal environments.

The tidal bundles in the present study are devoid of mud drapes representing mud deposition during high-tide slack-water periods. Well-defined mud drapes are present on the ebb-directed ripples in the spring-tide bundles (Fig. 11), but there are no signs of mud-drape deposition between the ebb-directed ripples and the underlying flood-directed cross-beds (Fig. 11). Instead, a faint erosional discontinuity demarcates the boundary between the two structures. A plausible explanation is that the mud drapes deposited during slack-water at high tide are subsequently eroded by the ebb current. Given the common occurrence of current speeds exceeding $0.2 \mathrm{~m} / \mathrm{s}$, and the counterclockwise rotation of the flood current during the slack-water period at high tide, it is unlikely that mud-drape deposition (or preservation) can occur. In cases when SSCs exceed $1 \mathrm{~g} / \mathrm{l}$, mud layers can be deposited in turbulent flows with current speeds appreciably over $0.2 \mathrm{~m} / \mathrm{s}$ (Baas et al., 2009). However, as SSCs of flood currents during spring tides are typically less than $300 \mathrm{mg} / \mathrm{l}$, dynamic mud deposition does evidently not occur (Mackay and Dalrymple, 2011). This assertion is in agreement 

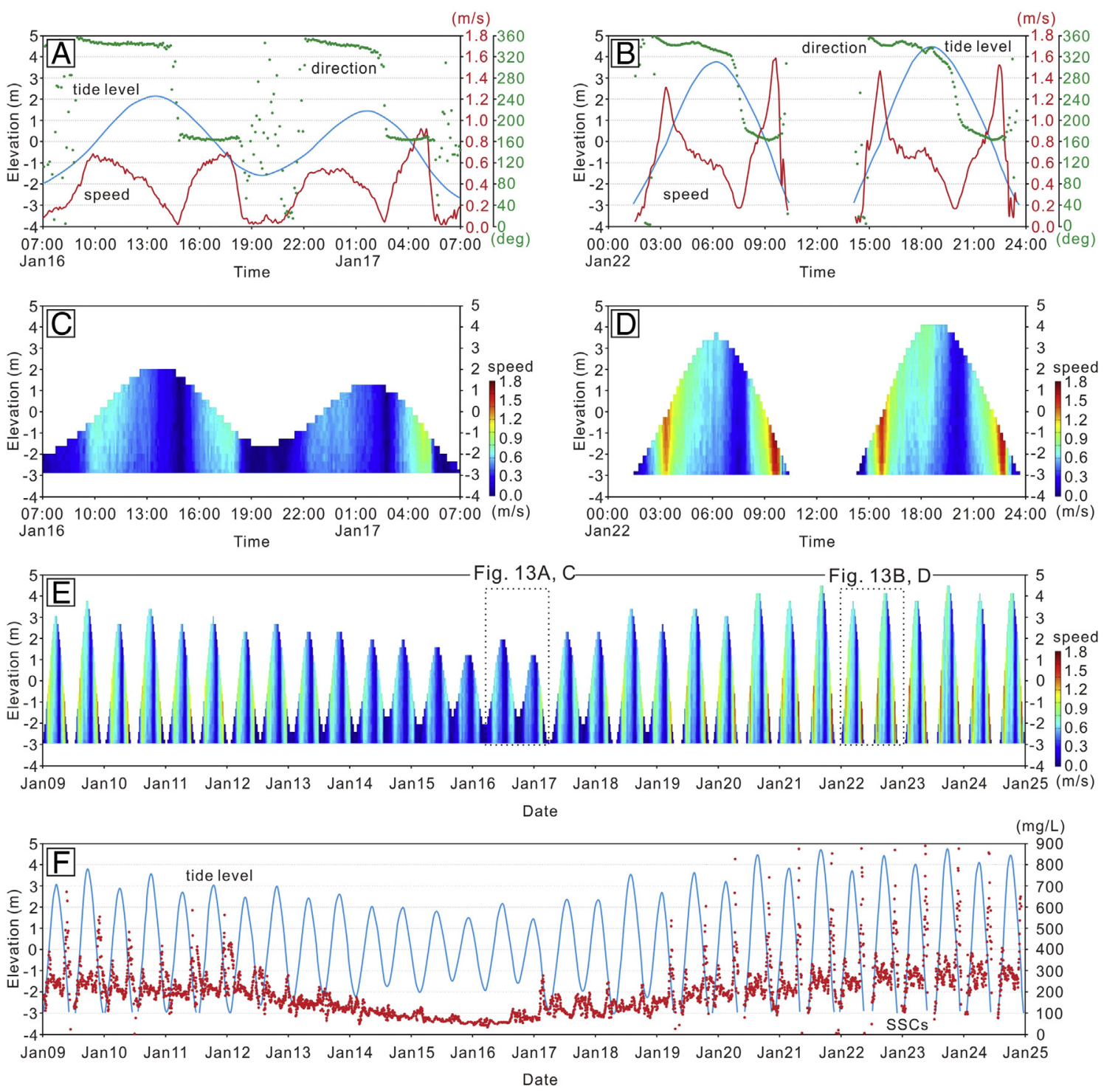

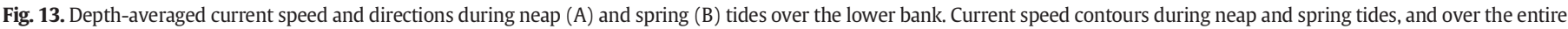

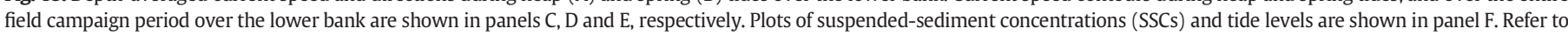
Fig. 1C for the location of the measurements (A2).

with the observed slight drop in SSCs during high-water slacks, which indicates that very little mud is deposited during this period (e.g., Winterwerp, 2002).

The thick mud drapes on the ebb-directed ripples are thinly stratified to cross-stratified and consist of silt and very fine sand. They exhibit gradational contacts with underlying ebb-directed ripples. The coarsegrained texture and stratified structure point to mud deposition under turbulent flow conditions with significant current speeds and high SSCs. The current data indicates that current speeds are about $0.2 \mathrm{~m} / \mathrm{s}$ just before the emergence of the lower-bank dunes during spring tides (Fig. 13B). The SSCs increase rapidly up to $900 \mathrm{mg} / \mathrm{l}$ during the peak ebb-current speed, which is followed by a sharp fall in the SSCs shortly after the velocity peaks (Fig. 13F), suggesting that significant mud deposition occurs during the ebbing tide in the intertidal zone. Field observation supplemented by sedimentological and hydrodynamic data indicates that the thick mud drapes are formed by the trapping of highly turbid water (fluid mud) in dune troughs during falling tides. Similar observations have been made in the channelized Gironde estuary, France (Fenies and Tastet, 1998; Fenies et al., 1999) and the Weser estuary, Germany (Schrottke et al., 2006). Tidal dunes tend to have more continuous and thicker mud drapes in their troughs toward spring tides when greater current speeds lead to an increase in SSC and subsequent suspension fallout to produce thicker mud drapes during the falling tides. The hydrodynamic dataset of this study indicates that SSCs vary in phase with tidal water level fluctuations (Figs. 12F, 13F). The elevated SSCS on the lower bank are attributable to the occurrence of a sharp ebb current peak within the channel produced by the pronounced velocity peak asymmetry. As the SSC lags behind the speed of the ebb current, it increases on the lower bank because of greater erosion and resuspension at the lower topographic elevation (e.g., Nowacki and Ogston, 2013; Ralston et al., 2013), which is congruent with field observations that the troughs of the lower-bank dunes are covered by thicker and more extensive mud drapes than those of the upper-bank dunes (Fig. 4A-C).

\subsection{Implication for paleoenvironmental reconstruction}

The present study demonstrates that tidal bundles in an open-coast macrotidal environment are inherently different from those in a channelized, mesotidal backbarrier setting. Firstly, in the former case, mud 


\section{Upper Bank}
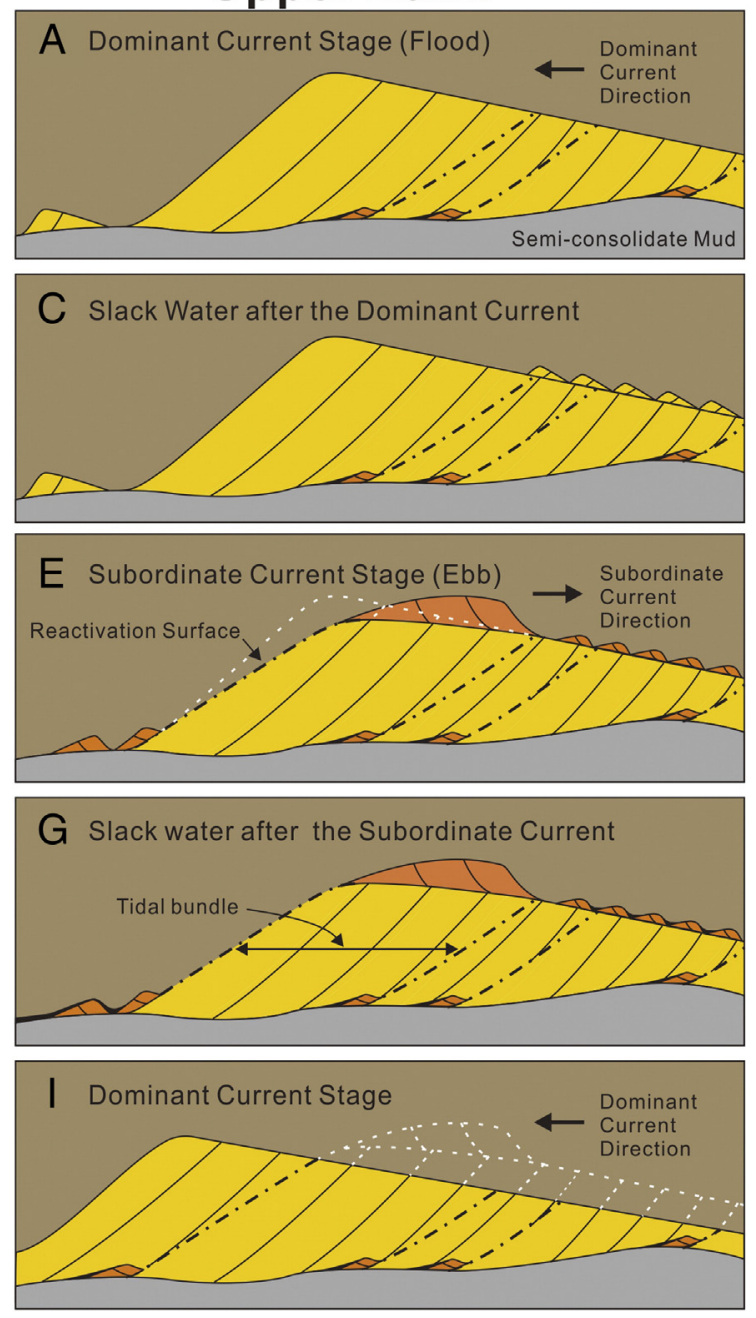

Lower Bank
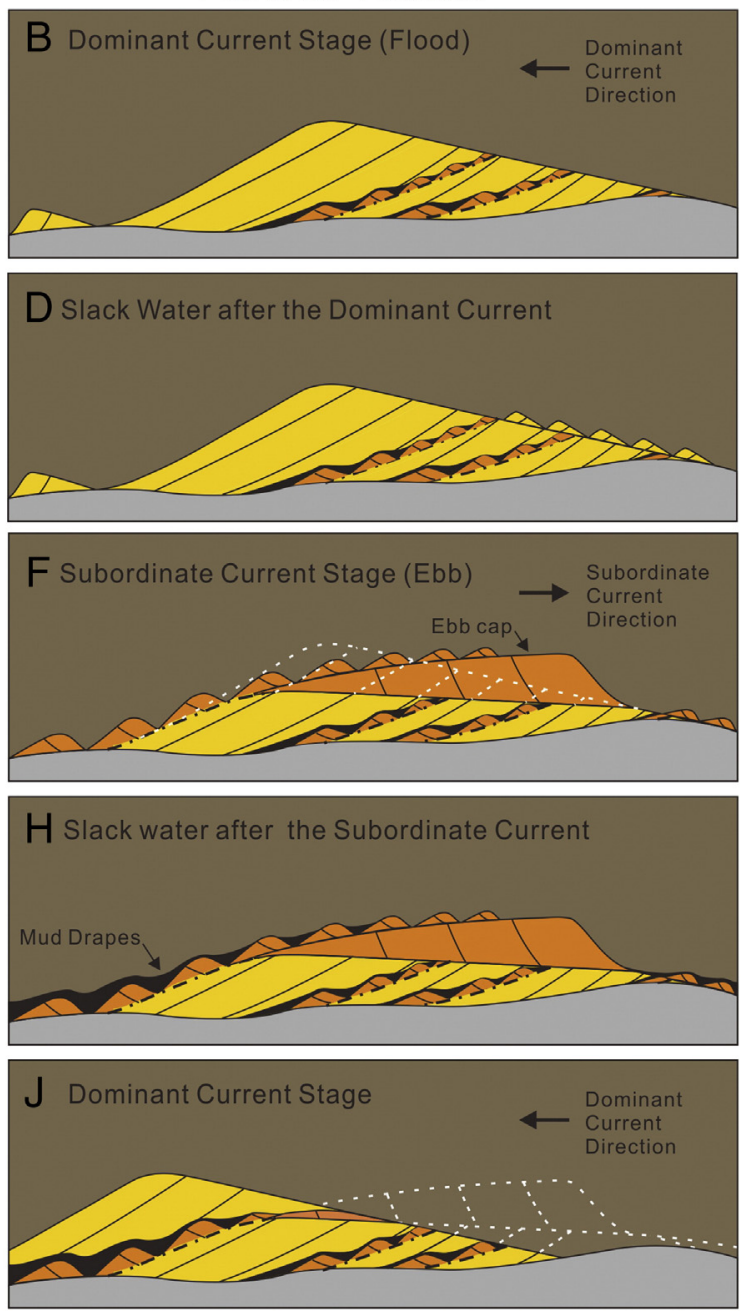

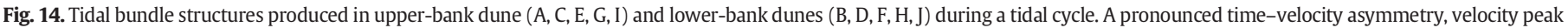

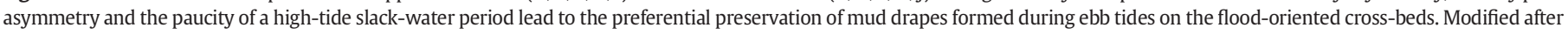
Visser (1980).

drapes representing the high-tide slack-water period are lacking, particularly during spring tides. The open-coast tidal flat has an unconfined morphologic setting that facilitates the occurrence of strong rotary currents during high tide similar to the open shelf (e.g., Pugh, 1987; Collins et al., 1998; Choi and Jo, 2015). In cases where the tidal flat is located seaward of the turbidity maximum, flood currents have low SSCs and are unlikely to produce thick mud drapes that would survive ensuing ebb currents. Mud deposition can take place when turbid water (fluid mud) is trapped in the dune troughs during falling tides. Therefore, single mud drapes tend to form during the course of one tidal cycle, regardless of the water depth in the channel. On the other hand, tidal currents in channelized settings are usually rectilinear and slacken during current reversals, which leads to the formation of double mud drapes in the subtidal zone and single mud drapes in the intertidal zone. Secondly, open-coast macrotidal environments tend to have thick mud drapes representing turbulent flow conditions during falling tides, with no quiescent slack-water period because of the occurrence of an ebb current peak in the lower intertidal zone along the tidal channels. Increased turbidity can be attained through prolonged erosion by ebb currents flowing over expansive tidal flats in macrotidal environments (e.g., Nowacki and Ogston, 2013; Ralston et al., 2013). Strong tidal currents combined with rapidly falling tide level leads to rapid settling of mud flocs while ripples are still in motion. Consequently the mud drapes tend to be coarser-grained, being enriched in silt and very fine sand, and displaying stratifications that may dip upslope. Deposition of unstratified mud drapes may occur during neap tides when dunes are immobile. In contrast, mud drapes in channelized estuarine settings are typically unstratified and rich in clay because of the turbidity maximum and well-established high-tide slack-water periods (Fenies and Tastet, 1998; Fenies et al., 1999; Schrottke et al., 2006; Deloffre et al., 2007; Van den Berg et al., 2007). Therefore, if tidal bundles contain single, stratified to cross-stratified mud drapes with silts and very fine sands deposited during the ebb current phase, then the depositional setting is likely to be an open-coast macrotidal environment where high-tide slack-water periods do not occur.

The mud-ripple relationship in the lower-bank dunes is similar to the drowning ripples documented in the fluvial-tidal transition of mesotidal environments (Van den Berg et al., 2007; Martinius and Van den Berg, 2011), except that the latter is coarser-grained due to the fluvial influence. On the other hand, the upward transition from crossstratification to opposite-directed ripples topped by thick and stratified mud drapes is almost identical in the two environments. Despite the similarity in sedimentary structures, the depositional conditions are quite contrasting. The former represents rapid suspension fallout from turbid water (fluid mud) trapped in dune troughs during falling tides in open-coast macrotidal and intertidal settings with negligible fluvial 
influence. The thick mud drapes originate from local current-induced erosion. In contrast, the latter points to mud deposition under turbulent flow conditions during high tides in channelized mesotidal settings with significant fluvial influence. The thick mud drapes are attributed to fluid mud originating from the turbidity maximum. Therefore, the use of drowning ripples as a diagnostic indicator of the transitional environments needs to be done with caution, unless the thick mud drapes alternate with thin mud drapes, the two constituting mud drape couplets (Van den Berg et al., 2007; Martinius and Van den Berg, 2011). Similar structures are also documented at the base of channels, where rapid flow deceleration of highly turbid waters associated with the turbidity maximum leads to a succession in which the ripple cross-lamination grades upward into either stratified or unstratified mud drapes (Mackay and Dalrymple, 2011). The presence or absence of stratification in the mud layers may be the key difference between channel-based fluid mud deposits and mud drapes on dunes in opencoast macrotidal environments. The latter is typically stratified.

The present study has demonstrated that the tidal dunes on the upper bank consist of predominantly flood-directed cross-beds with better-developed hierarchical tidal cycles in their bundle structures (Fig. 15). In general, protected locations such as headward or seaward terminating, flood- or ebb-dominant channels (e.g., Dalrymple, 2010), or subtidal channels sheltered by a bar (Martinius and Van den Berg, 2011), are favorable sites for such rhythmic sedimentation. However, the tidal dunes in the present study are neither protected by a channel-attached bar nor located in a barb. Despite their location in an unprotected setting, the pronounced velocity peak and time-velocity asymmetries lead to a flood-tide dominance with little ebb-tide influence and the promotion of rhythmic bundle preservation at higher elevations in the intertidal zone (Fig. 15). The subtidal channels in the study area exhibit a distinct time-velocity asymmetry with an ebbtide dominance (Choi and Jo, 2015). However, preservation of rhythmic tidal bundles is unlikely because both flood and ebb currents are strong enough to reverse dune profiles during each tidal cycle. The sedimentary record of rhythmic tidal deposition produced by preceding tidal currents can easily be obliterated by ensuing tidal currents. The sudden increase in tidal prism caused by the overtopping of the channel bank produces a current peak during the flood tide and flow convergence toward the channel during the subsequent ebb tide (Bayliss-Smith et al., 1979). As a result the velocity peak asymmetry increases proportional to the travel time of currents over the intertidal flat (Fagherazzi et al., 2008). Consequently, the impact of the asymmetry is more pronounced on the wider tidal flats of macrotidal environments than on the narrower tidal flats of channelized mesotidal environments (e.g., Fenies et al., 1999; Lee et al., 1999; Mariotti and Fagherazzi, 2011). Also intertidal zones are more sensitive to the velocity peak asymmetry than subtidal zones, because of the depth-limited conditions in the former. In other words, the greater the velocity peak asymmetry, the greater the domination of the intertidal zone by flood-dominated cross-beds due to the shorter duration of strong ebb currents. Therefore, an idealized succession formed by tidal dunes in macrotidal and intertidal channels will be mainly characterized by flood-oriented cross-beds and a minor occurrence of ebb-directed ripples (Fig. 15). However, the paucity of larger, ebbdirected cross-beds does not necessarily mean that ebb currents are weak because it could, quite counterintuitively, also be due to the fact that, although ebb currents may be stronger enough, they are of shorter duration than flood currents due to a stronger morphological feedback in open-coast macrotidal environments.

\section{Conclusions}

Tidal dunes are present in the lower intertidal zone of an open-coast macrotidal environment in the northern Gyeonggi Bay, west coast of Korea. The morphology of the tidal dunes varies from symmetric to

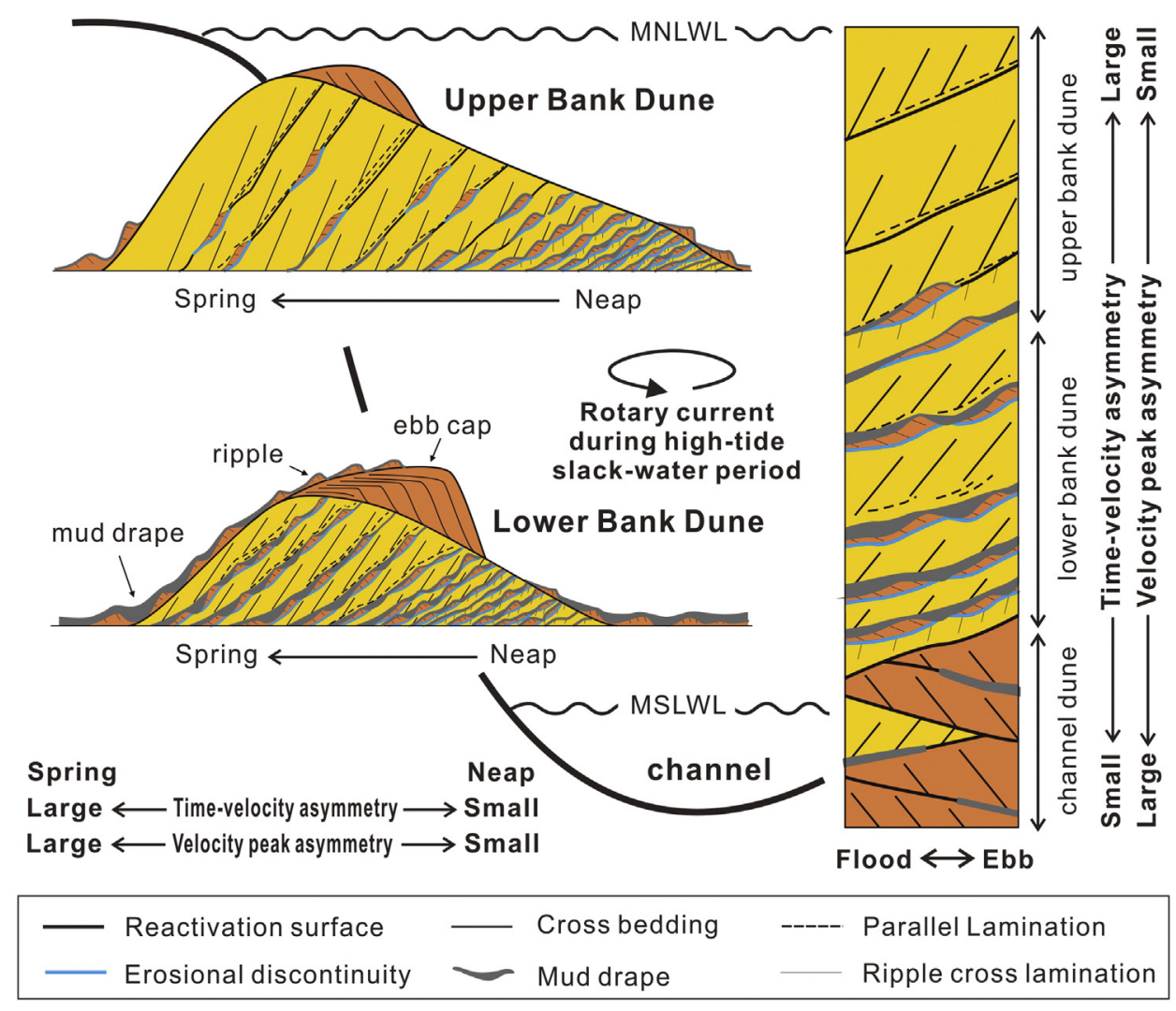

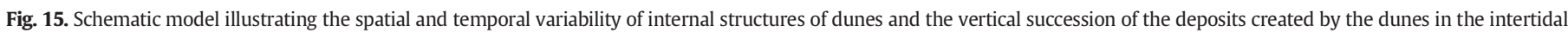
zone of an open-coast macrotidal environment. MNLWL and MSLWL denote mean neap low water level and mean spring low water level, respectively. 
ebb-asymmetric with large ebb caps on the lower bank to floodasymmetric with smaller ebb caps on the upper bank. The tidal dunes on the upper bank are characterized by flood-oriented, steeplydipping tabular cross-beds with thin mud drapes, whereas those on the lower bank are dominated by flood-oriented, low-angle tabular cross-beds with thick mud drapes. Tidal bundles contain single mud drapes formed during ebb tides and not during the high-tide slackwater periods, as might be expected. The mud drapes consist of stratified to cross-stratified silt and very fine sand, suggesting dynamic mud deposition during ebb tides. The absence of mud drapes deposited during hightide slack-water periods results from the presence of strong rotary currents during that period and the low suspended-sediment concentrations of flood currents. Tidal bundles exhibit hierarchical tidal cycles, with longer cycles being better preserved in the tidal dunes on the upper bank. The persistent occurrence of single stratified to cross-stratified mud drapes deposited during the ebb current phase, and the dominance of flood-directed cross-beds with ebb-oriented ripples, are considered to represent diagnostic criteria of tidal bundles formed in open-coast macrotidal environments. Pronounced velocity peak asymmetry leads to stronger but short-lived ebb currents that have insufficient time to reverse dune profiles because the peaks occur at much lower water elevations than those of the flood currents. Therefore, caution is advised when interpreting the dominance of flood-directed cross-beds in tidal bundle successions formed in the intertidal zone of open-coast macrotidal environments. The present study demonstrates that distinct time-velocity asymmetry, velocity peak asymmetry and the paucity of the high-tide slack-water period due to the unconfined morphologic setting differentiate tidal bundles in open-coast macrotidal environments from those in channelized mesotidal environments.

\section{Acknowledgments}

This study has been partially supported by the Energy Efficiency and Resources Planning (KETEP) grant funded by the Ministry of Trade, Industry and Energy (MOTIE) (2013251010005A), Republic of Korea, and the Research Institute of Oceanography at Seoul National University. The authors wish to thank Don Cummings for the English correction on the earlier version of the manuscript. Extensive and insightful reviews by two anonymous reviewers and Jasper Knight greatly improved the paper.

\section{References}

Abouessa, A., Duringer, P., Schuster, M., Pelletier, J., Rubino, J.L., 2014. Small-scale sedimentary structures and their implications in recognizing large-scale ancient tidal bedforms. Example from Dur At Talah outcrop, Late Eocene, Sirt Basin, Libya. Journal of African Earth Sciences 100, 346-364.

Ashley, G.M., 1990. Classification of large-scale subaqueous bedforms: a new look at an old problem. Journal of Sedimentary Petrology 60, 160-172.

Baas, J.H., Best, J.L., Peakall, J., Wang, M., 2009. A phase diagram for turbulent, transitional and laminar clay suspension flows. Journal of Sedimentary Research 79, 162-183.

Bayliss-Smith, T.P., Healy, R., Lailey, R., Spencer, T., Stoddart, D.R., 1979. Tidal flows in salt marsh creeks. Estuarine and Coastal Marine Science 9, 235-255.

Boersma, J.R., 1969. Internal structure of some tidal mega-ripples on a shoal in the Westerschelde estuary, the Netherlands-report of a preliminary investigation. Geologie en Mijnbouw 48, 409-414.

Boersma, J.R., Terwindt, J.H.J., 1981. Neap-spring tide sequences of intertidal shoal deposits in a mesotidal estuary. Sedimentology 28, 151-170.

Choi, K.S., Jo, J.H., 2015. Morphodynamics and stratigraphic architecture of compound dunes on the open-coast macrotidal flat in the northern Gyeonggi Bay, west coast of Korea. Marine Geology 366, 34-48.

Collins, M.B., Ke, X., Gao, S., 1998. Tidally-induced flow structure over intertidal flats. Estuarine, Coastal and Shelf Science 46, 233-250.

Cummings, D.I., Dalrymple, R.W., Choi, K., Jin, J.H., 2016. The Tide-Dominated Han River Delta, Korea-Geomorphology, Sedimentology and Stratigraphic Architecture. Elsevier, Amsterdam (376 pp.).

Dalrymple, R.W., 1984. Morphology and internal structure of sandwaves in the Bay of Fundy. Sedimentology 31, 365-382.

Dalrymple, R.W., 2010. Tidal depositional systems. In: James, N.P., Dalrymple, R.W. (Eds.), Facies Model 4. Geological Association of Canada, St. John's, pp. 59-72.

Dalrymple, R.W., Rhodes, R.W., 1995. Estuarine dunes and barforms. In: Perillo, G.M. (Ed.), Geomorphology and Sedimentology of EstuariesDevelopments in Sedimentology. Elsevier, Amsterdam, pp. 359-422.
Dalrymple, R.W., Makino, Y., Zaitlin, B.A., 1991. Temporal and spatial patterns of rhythmite deposition on mud flats in the macrotidal Cobequid Bay-Salmon River estuary, Bay of Fundy, Canada. In: Smith, D.G., Reinson, G.E., Zaitlin, B.A., Rahmani, R.A. (Eds.), Clastic Tidal Sedimentology. Canadian Society of Petroleum Geologists, Memoir 16, pp. 127-160.

De Boer, P.L., Oost, A.P., Visser, M.J., 1989. The diurnal inequality of the tide as a parameter for recognizing tidal influence. Journal of Sedimentary Petrology 59, 912-921.

De Mowbray, T., Visser, M.J., 1984. Reactivation surfaces in subtidal channel deposits, Oosterschelde, southwest Netherlands. Journal of Sedimentary Petrology 54, 811-824.

Deloffre, J., Verney, R., Lafite, R., Lesueur, P., Lesourd, S., Cundy, A.B., 2007. Sedimentation on intertidal mudflats in the lower part of macrotidal estuaries: sedimentation rhythms and their preservation. Marine Geology 241, 19-23.

Eriksson, K.A., Simpson, E.L., 2000. Quantifying the oldest tidal record: 3.2 Ga Moodies Group, Barberton greenstone Belt, South Africa. Geology 28, 831-834.

Fagherazzi, S., Hannion, M., D'Odorico, P., 2008. Geomorphic structure of tidal hydrodynamics in salt marsh creeks. Water Resources Research 44, W02419. http://dx.doi. org/10.1029/2007WR006289.

Fenies, H., Tastet, J.-P., 1998. Facies and architecture of an estuarine tidal bar (the Trompeloup bar, Gironde Estuary, SW France). Marine Geology 150, 149-169.

Fenies, H., De Resseguier, A., Tastet, J.-P., 1999. Intertidal clay-drape couplet (Gironde estuary, France). Sedimentology 46, 1-15.

Flemming, B.W., 2012. Siliciclastic back-barrier tidal flats. In: Davis, R.A., Dalrymple, R.W. (Eds.), Principles of Tidal Sedimentology. Springer, Dordrecht, pp. 231-267.

KMA (Korea Meteorological Administration), 2013. Annual Climatological Report (Year 2012). Publication No. 11-1360000-00016-10, Seoul (312 pp.).

Kvale, E.P., Archer, A.W., 1991. Characteristics of two Pennsylvanian-age semidiurnal tidal deposits in the Illinois Basin, U.S.A. In: Smith, D.G., Reinson, G.E., Zaitlin, B.A., Rahmani, R.A. (Eds.), Clastic Tidal Sedimentology. Canadian Society of Petroleum Geologists, Memoir Vol. 16, pp. 179-188.

Lee, H.J., Chu, Y.S., Park, Y.A., 1999. Sedimentary processes of fine-grained material and the effect of seawall construction in the Daeho macrotidal flat-nearshore area, northern west coast of Korea. Marine Geology 157, 171-184.

Lee, H.J., Park, J.Y., Lee, S.H., Lee, J.M., Kim, T.K., 2013. Suspended sediment transport in a rock-bound, macrotidal estuary: Han Estuary, Eastern Yellow Sea. Journal of Coastal Research 29, 358-371

Legler, B., Johnson, H.D., Hampson, G., Massart, B.Y.G., Jackson, C.A.L., Jackson, M.D., ElBarkooky, A., Ravnas, R., 2013. Facies model of a fine-grained, tide-dominated delta: Lower Dir Abu Lifa Member (Eocene), Western Desert, Egypt. Sedimentology 60, $1313-1356$

Longhitano, S.G., 2011. The record of tidal cycles in mixed silici-bioclastic deposits: examples from small Plio-Pleistocene peripheral basins of the microtidal Central Mediterranean Sea. Sedimentology 58, 691-719.

Longhitano, S.G., Mellere, D., Steel, R.J., Ainsworth, R.B., 2012. Tidal depositional systems in the rock record: a review and new insights. Sedimentary Geology 279, 2-22.

Mackay, D.A., Dalrymple, R.W., 2011. Dynamic mud deposition in a tidal environment: the record of fluid-mud deposition in the Cretaceous Bluesky Formation, Alberta, Canada. Journal of Sedimentary Research 81, 901-920.

Mariotti, G., Fagherazzi, S., 2011. Asymmetric fluxes of water and sediments in a mesotidal mudflat channel. Continental Shelf Research 31, 23-36.

Martinius, A.W., Van den Berg. J.H., 2011. Atlas of Sedimentary Structures in Estuarine and Tidally-Influenced River Deposits of the Rhine-Meuse-Scheldt System. EAGE Publications BV, Houten (298 pp.).

Nio, S.D., Yang, C.S., 1991. Diagnostic attributes of clastic tidal deposits: a review. In: Smith, D.G., Reinson, G.E., Zaitlin, B.A., Rahmani, R.A. (Eds.), Clastic Tidal Sedimentology. Canadian Society of Petroleum Geologists, Memoir Vol. 16, pp. 3-28.

Nowacki, D.J., Ogston, A.S., 2013. Water and sediment transport of channel-flat systems in a mesotidal mudflat: Willapa Bay, Washington. Continental Shelf Research 60S, S111-S124.

Pethick, J.S., 1980. Velocities, surges and asymmetry in tidal channels. Estuarine and Coastal Marine Science 11, 331-345.

Pugh, D.T., 1987. Tides, Surges and Mean Sea-Level. John Wiley and Sons, Chichester (472 pp.).

Ralston, D.K., Geyer, W.R., Traykovski, P.A., Nidzieko, N.J., 2013. Effects of estuarine and fluvial processes on sediment transport over deltaic tidal flats. Continental Shelf Research 60S, S40-S57.

Reynaud, J.Y., Ferrandini, M., Ferrandini, J., Santiago, M., Thinon, I., Andre, J.P., Barthet, Y., Guennoc, P., Tessier, B. 2013. From non-tidal shelf to tide-dominated strait: the Miocene Bonifacio Basin, Southern Corsica. Sedimentology 60, 599-623.

Schrottke, K., Becker, M., Bartholomä, A., Flemming, B.W., Hebbeln, D., 2006. Fluid mud dynamics in the Weser estuary turbidity zone tracked by high-resolution side-scan sonar and parametric sub-bottom profiler. Geo-Marine Letters 26, 185-198.

Tape, C.H., Cowan, C.A., Runkel, A.C., 2003. Tidal-bundle sequences in the Jordan Sandstone (Upper Cretaceous), southeastern Minnesota, U.S.A.: evidence for tides along inboard shorelines of the Sauk epicontinental sea. Journal of Sedimentary Research 73, 354-366.

Terwindt, J.H.J., Brouwer, M.J.N., 1986. The behavior of intertidal sandwaves during neapspring tide cycles and the relevance for palaeoflow reconstructions. Sedimentology $33,1-31$

Tirsgaard, H., 1993. The architecture of Precambrian high energy tidal channel deposits: an example from the Lyell Land Group (Eleonore Bay supergroup), northeast Greenland. Sedimentary Geology 88, 137-152.

Van den Berg, J.H., Boersma, J.R., Van Gelder, A., 2007. Diagnostic sedimentary structures of the fluvial-tidal transition zone-evidence from deposits of the Rhine and Meuse. Netherlands Journal of Geosciences 86, 287-306.

Visser, M.J., 1980. Neap-spring cycles reflected in Holocene subtidal large-scale bedform deposits: a preliminary note. Geology 8, 543-546. 
Williams, G.E., 1991. Upper Proterozoic tidal rhythmites, South Australia: sedimentary features, deposition, and implications for the Earth's paleorotation. In: Smith, D.G., Reinson, G.E., Zaitlin, B.A., Rahmani, R.A. (Eds.), Clastic Tidal Sedimentology. Canadian Society of Petroleum Geologists, Memoir 16, pp. 161-177.
Winterwerp, J.C., 2002. On the flocculation and settling velocity of estuarine mud. Continental Shelf Research 22, 1339-1360.

Yang, C.S., Nio, S.D., 1985. The estimation of paleo-hydrodynamic processes from subtidal deposits using time series analysis method. Sedimentology 32, 41-57. 